\begin{tabular}{|c|c|c|}
\hline Beitr. Ent. & Keltern & ISSN 0005-805X \\
\hline $\mathbf{5 2 ( 2 0 0 2 ) 2}$ & S. 367-405 & 16.12 .2002 \\
\hline
\end{tabular}

\title{
Casebearers (Lepidoptera: Coleophoridae) of the Far East region of Russia. I.
}

\section{(Contribution to the knowledge of the Eastern Palaearctic Insects 12)}

With 19 figure plates

GIORGIO BALDIZZONE(1) and NiKOLAY SAVENKOV

Summary

The present paper is based on material collected by the second author during the expedition to the Russian Far East in the summer of 1994, as well as some material of other collectors from the same region, including material from the Far East expedition 1993 of the DEI Eberswalde, supported by the German Research Society (DFG). In all almost 900 specimens were examined. Seven species are described here as new for science-Coleophora teregnathella, C. kononenkoi, C. okuella, C. rapbidon, C. irinae, C.parki, C. napolovi. 42 previously known species were identified, of which five are new for the fauna of Asia.

\section{Zusammenfassung}

Die vorliegende Arbeit basiert auf Material, welches der Zweitautor während einer Expedition im Sommer 1994 in den Fernen Osten Russlands gesammelt hat, sowie auf weiterem Material anderer Sammler aus der gleichen Region, einschließlich der Falter der Fernost-Expedition 1993 des DEI (unterstützt durch die Deutsche Forschungsgemeinschaft DFG). Es wurden fast 900 Exemplare untersucht. Sieben Arten werden als neu für die Wissenschaft beschrieben - Coleophora teregnathella, C. kononenkoi, C. okuella, C. raphidon, $C$. irinde, C. parki, C. napolovi. 42 bisher schon bekannte Arten wurden festgestellt, von diesen sind fünf neu für die Fauna Asiens.

Key words

Lepidoptera, Coleophoridae, Far East of Russia, Japan, new species.

The following abbreviations are used:

LMNH Latvian Museum of Natural History, R ga

LIE Lithuanian Institute of Ecology, Vilnius

DEI Deutsches Entomologisches Institut im ZALF, Eberswalde

ZMH Zoological Museum Helsinki

(1) Contribution to the knowledge of Coleophoridae. XCIV 
Despite the growing interest and attention given to casebearers (Coleophoridae) they remain one of the poorest studied Lepidoptera-groups in Eastern Asia during recent years. Substantial progress was made through the efforts of OKU $(1965,1974)$, FALKOVITSH (1972-1979), FALKOVITSH \& REZNIK (1980), REZNIK (1974-1977), BALDIZZONE \& OKU (1988-1990), BALDIZZONE (1989), PARK \& BALDIZZONE (1992), ANIKIN (1998, 1999), LI \& ZHUNG (2000).

During the period from 13 July to 7 August of 1994 the junior author took part in the expedition to the Far East of Russia in the vicinity of Vladivostok (Primorskij Kraj). Almost all material was collected at light in the village of Anisimovka. The surroundings were the slopes of the South Sikhote Alin', covered with secondary mostly deciduous forests, dry meadows and individual gardens. More than 720 specimens of Coleophoridae were obtained. About 130 specimens were also obtained in this region in 1989-1991 and loaned by A. NAPOLOV.

While determining the material many unknown species were met, so the junior author turned to the senior author for help. About 60 species of Coleophoridae were recognized. Seven species - Coleophora teregnatbella, C. kononenkoi, C. okuella, C. rapbidon, C. irinae, C. parki, C. napolovi - are described here as new for science. C. platyphyllae, previously synonymized with $C$. zelleriella HEINEMANN, 1854, was reinstated as a species. 42 species were identified with already known species, five of which (C. albidella (DENIS \& SCHIFFERMÜller, 1775), C. trocbilella (DUPONCHEL, 1843), C. linosyridella FUCHS, 1880, C. striatipennella TENGSTRÖM in NYLANDER [1848], C. unipunctella ZELLER, 1849) are new for the fauna of Asia. C. cristata BALDIZZONE, 1989, C. falkovitshella Vrves, 1984, C. linosyridella FuCHS, 1880, C. adspersella BENANDER, 1939, and C. clypeiferella HOFMANN, 1871 are reported from Japan for the first time.

Type material is kept in the collection of Latvian Museum of Natural History, some paratypes in the collection of Dr. G. BALDIZZONE, one paratype in the coll. of the DEI Eberswalde.

\section{The list of species}

\section{Coleophora ulmivorella OKU, 1965}

Far East of Russia:

8 ơ, 3 ㅇ, Primorskij Kraj, Shkotovo distr., Anisimovka, 17-27.07.1994 (N. SAVENKOV). In coll. LMNH and in coll. G. BALDIZZONE.

Geographical distribution: Far East of Russia, Korea, Japan.

Coleophora milvipennis ZELLER, 1839

Far East of Russia:

15 ơ, 7 우, Primorskij Kraj, Shkotovo distr., Anisimovka, 13.07-04.08.1994 (N. SAVENKOV). In coll. LMNH and in coll. G. BALDIZZONE.

Geographical distribution: Palaearctic: Europe, Turkey, Central and Eastern Siberia, Japan. 
Coleophora japonicella OKU, 1965

Far East of Russia:

1 을 Primorskij Kraj, Hasan distr., Barabash, 29.07.1989 (A. NAPOLOV);

$130^{\star}, 12$ 우, Primorskij Kraj, Shkotovo distr., Anisimovka, 13.07-07.08.1994 (N. SAVENKOV). In coll. LMNH and in coll. G. BALDIZZONE.

Geographical distribution: Far East of Russia, Japan.

Coleophora mayrella (HÜBNER, 1813)

Far East of Russia:

6 o, Primorskij Kraj, Shkotovo distr., Anisimovka, 13-16.07.1924 (N. SAVENKOV). In coll. LMNH.

Geographical distribution: Holarctica.

Coleophora deauratella LIENIG \& ZELLER, 1846

Far East of Russia:

$1 \sigma^{\star}$, Primorskij Kraj, Shkotovo distr., Anisimovka, 20.07 .1994 (N. SAVENKOV). In coll. LMNH.

Geographical distribution: Palaearctic: Europe, Tunisia, Turkey, Lebanon, Eastern Siberia, China. - Nearctic: U.S.A., Canada.

\section{Coleophora trifolii (CURTTS, 1832)}

Far East of Russia:

$1 \sigma^{*}, 2$ \%, Primorskij Kraj, Shkotovo distr., Anisimovka, 20-27.07.1994 (N. SAVENKOV). In coll. LMNH.

Geographical distribution: Palaearctic: Europe, North Africa, Turkey, Afghanistan, China. - Nearctic: U.S.A., Canada.

\section{Coleophora alcyonipennella (KOLLAR, 1832)}

Far East of Russia:

20,2 ㅇ, Primorskij Kraj, Ussurijsk distr., Gornotajozhnoje, 24-26.08.1989 (A. NAPOLOV);

$40^{\star}, 1$ q, Primorskij Kraj, Hasan distr., Bamburovo, 12-17.08.1990 (A. NAPOLOV);

5 o , Primorskij Kraj, Hasan distr., Zanadvorovka, 21.08.1991 (A. NAPOLOV);

6 o , 4 q, Primorskij Kraj, Shkotovo distr., Anisimovka, 13-31.07.1994 (N. SAVENKOV). In coll. LMNH;

1 o, Primorskij Kraj, Ussuyisky Reserve, $30 \mathrm{~km}$ SE Ussuriysk, 43.3N 132OE, 28.07- 
01.08.1993 (C. KUTZSCHER). In coll. DEI.

Geographical distribution: Palaearctic: Europe, Morocco, Turkey, Iraq, Iran, Afghanistan, Pakistan, China, Japan. - Australasia: Australia, New Zealand.

Coleophora albidella (DENIS \& SCHIFFERMÜLLER, 1775)

Far East of Russia:

14 o, 1 ㅇ, Primorskij Kraj, Shkotovo distr., Anisimovka, 13-29.07.1994 (N. SAVENKOV). In coll. LMNH.

Geographical distribution: Palaearctic (Europe, Far East of Russia).

New for Asia!

\section{Coleophora platyphyllae OKU, 1965 bona sp.}

This species was previously synonymized with C. zelleriella HEINEMANN, 1854 (BALDIZZONE, 1981). The investigation of new material (especially females) confirmed the status of this taxon as a good species.

Male genitalia (figs 1-4), female genitalia (figs 5-7).

Far East of Russia:

10 o 2 ㅇ, Primorskij Kraj, Shkotovo distr., Anisimovka, 19.07-05.08.1994 (N. SAVEN$\mathrm{KOV})$. In coll. LMNH and in coll. G. BALDIZZONE.

Geographical distribution: Far East of Russia, Japan.

Coleophora quercicola BALDIZZONE \& OKU, 1990

Far East of Russia:

8 o , Primorskij Kraj, Shkotovo distr., Anisimovka, 14-18.07.1994 (N. SAVENKOV). In coll. LMNH and in coll. G. BALDIZZONE.

Geographical distribution: Far East of Russia, Korea, Japan.

Coleophora melanograpta MEYRICK, 1935

Far East of Russia:

$1 \sigma^{*}$, Primorskij Kraj, Hasan distr., Barabash, 13.07 .1989 (A. NAPOLov);

$110^{\star}$, Primorskij Kraj, Shkotovo distr., Anisimovka, 13-20.07.1994 (N. SAVENKOV). In coll. LMNH and in coll. G. BALDIZZONE.

Geographical distribution: Far East of Russia, Korea, Japan. 
Coleophora teregnathella BALDIZZONE \&.SAVENKOV n. sp.

(figs 8-11)

Description: Wingspan about $12-13 \mathrm{~mm}$. Antenna white with well-developed basal hairtuft; flagellum annulated with brownish more distinctly on terminal half. Labial palpus short, white; median joint roughly as long as diameter of eye; terminal joint about $1 / 2$ of median joint. Head and thorax white. Forewing white, marked with dark brown along the extreme costa, brownish suffusion often forming distinct streaks along veins, the degree of its development variable; costo-apical fringe dark brown, tipped with white; cilia greyish. Hindwing and cilia grey. Legs and abdomen whitish.

Female: Unknown.

Male genitalia (figs 8-10): Gnathos small and narrow, cone-shaped, supported by long dorsal arm of tegumen; tegumen trapezoidal, broad, with short ventral arms; transtilla horn-shaped, gradually narrowed towards the tip, which is slightly raised; valva long and narrow, irregularly bristled, slightly dilated apically; valvula broad, irregularly bristled, with broadly rounded ventro-terminal edge; sacculus about twice as long as wide, strongly sclerotized in terminal $1 / 4$, ventro-terminal edge with small triangular process; phallotheca quite small, simple; cornuti thin, thorn-like, 10 or more in number, arranged in a long linear row.

Structure of abdominal supports (fig. 11): The $1^{\text {st }}$ tergite without spinelets; proximal fold of caudal rib very narrow and present only at both ends, atrophied for most of its length, distal fold narrow, strong and straight; in the following tergites spinelet patches rather compact, rounded, of almost equal length and width, with 20 or more spinelets on each of tergites $2-4$.

Holotype: $o^{\top}$ (GP BLDZ 11 603), Far East of Russia, Primorskij Kraj, Shkotovo distr., Anisimovka, 20.07.1994 (N. SAVENKOV), in coll. LMNH.

Paratypes: 990

78 o $\sigma^{*}$ : Same locality, same collector:

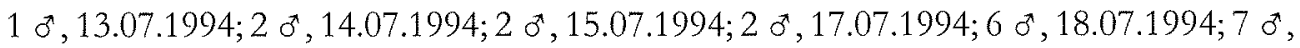
19.07.1994; $17 \sigma^{\pi}, 20.07 .1994 ; 6 \sigma^{\star}, 21.07 .1994 ; 6$ o, 22.07.1994; 1 o, 23.07.1994; $2 \sigma^{\star}$, 24.07.1994; 7 o, 25.07.1994; 2 o, 26.07.1994; 5 क , 27.07.1994; 6 o, 28.07.1994; 3 क, 29.07.1994; $2 \sigma^{\circ}, 30.07 .1994 ; 10,01.08 .1994$. In coll. LMNH and in coll. G. BALDIZZONE;

3 o , Far East, Primorje, Kedrovayia Padj, leg. IvINSKIs:

10 (GP BLDZ 12980), 29.07.1988; 1 o (GP BLDZ 12985), 4.8.1988; 1 o (GP BLDZ 12990), 7.08.1988. In coll. LIE and in coll. G. BALDIZZONE;

$180^{\circ}$, leg. JALAVA, KULlBERG \& KAARE, in coll. ZMH and in coll. J. TABELl:

$30^{\circ}$, S. Primorje 430 10’ N, $132^{\circ} 46^{\prime} \mathrm{E}$, Anisimovka 300m, 24.-28.7.1998;

$140^{\star}$ (GP JT 3246, 3448), S. Primorje $43^{\circ} 38^{\prime} \mathrm{N} 32^{\circ} 33^{\circ} \mathrm{E}$, Ussuriskij Res. 250m, 29.31.7.1998;

$10^{\prime}$, S. Primorje 43 $16^{\prime} \mathrm{N} 134^{\circ} 08^{\prime} \mathrm{E}$, Lazovski Res. 180m, 5.-9.8.1998.

Bionomics: The foodplant and the early stages are unknown. 
Distribution: Far East of Russia (Primorskij Kraj).

Remarks: The new species belongs to the $16^{\text {th }}$ species group of ToLL's (1952) system, which includes so-called pistol-case bearers. Externally it can be compared with C. Yelleriella HEINEMANN, 1854 or C. betulella HEINEMANN, 1877 . In the male genitalia it is most similar to $C$. zelleriella, differing by the much stronger ventral process of sacculus and very small, narrow gnathos.

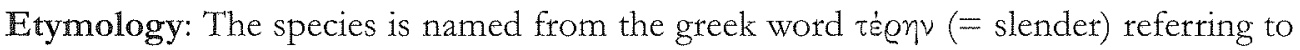
the gnathos shape.

\section{Coleophora kononenkoi BALDIZZONE \& SAVENKOV n. sp.}

(figs 12-15)

Description: Wingspan about $12 \mathrm{~mm}$. Antenna white, with well developed basal hairtuft; flagellum has indistinct annulation only on terminal half. Labial palpus short, white; median joint roughly as long as diameter of eye; terminal joint about $1 / 2$ of median joint. Head and thorax white. Forewing white with brownish suffusion often forming distinct streaks along veins, costo-apical fringe brownish; cilia brownish-grey. Hindwing and cilia grey. Legs and abdomen whitish.

Female: Unknown.

Male genitalia (figs 12-14): Gnathos globular; tegumen rather narrow, somewhat trapezoidal, with moderately short dorsal and ventral arms; transtilla tharrow; valva narrow and moderately long, strongly narrowed in basal part, with rounded ventro-terminal edge; valvula broad suboblong, irregularly bristled; sacculus about 1.5 times longer than wide, strongly sclerotized in terminal 1/4; phallotheca small, simple; cornuti thin, thornlike, 10 or more in number, arranged in a long linear row.

Structure of abdominal supports (fig. 15): The $1^{\text {st }}$ tergite without spinelets; proximal fold of caudal rib narrow, much stronger in the central part, distal fold stronger and wider on both ends, slightly atrophied centrally; in the following tergites spinelet patches rather compact, somewhat irregular in shape, slightly longer than wide, with 23-25 or more spinelets on each of tergites 2-4.

Holotype: $\sigma^{*}$ (GP BLDZ 11692), Far East of Russia, Primorskij Kraj, Shkotovo distr., Anisimovka, 20.07.1994 (N.SAVENKOV), in coll. LMNH.

Paratypes: 30 , same locality, same collector, in coll. LMNH:

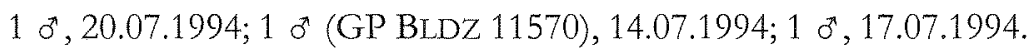

Bionomics: The foodplant and the early stages are unknown.

Distribution: Far East of Russia (Primorskij Kraj).

Remarks: Like the previous species, belongs to the 16 species group of TOLL's (1952) system. In superficial appearance the new species can be compared with C. zelleriella HEINEMANN, 1854, or C. betulella HEINEMANN, 1877. In the male genitalia it is most similar to $C$. betulella, differing by the shorter valva and broader sacculus.

Etymology: the species is named in the honour of Dr. VLADIMIR KONONENKO, a well known investigator of East Asian Noctuidae. 
Coleophora honshuella BALDIZZONE \& OKU, 1988

Far East of Russia:

1 o , 4 o , Primorskij Kraj, Shkotovo distr., Anisimovka, 25-31.07.1994 (N. SAVENKOV). In coll. LMNH and in coll. G. BALDIZZONE.

Geographical distribution: Far East of Russia, Japan.

Coleophora caelebipennella ZELLER, 1839

Far East of Russia:

1 ơ, 1 o , Primorskij Kraj, Shkotovo distr., Anisimovka, 16.07.1994 (N. SAVENKov). Ibidem, 20.07.1994 (N. SAVENKOV). In coll. G. BALDIZZONE.

Geographical distribution: Palaearctic: Europe, Turkey, North Africa, Afghanistan Pakistan.

Coleophora adjunctella HODGKINSON, 1882

Far East of Russia:

4 o, 1 o , Primorskij Kraj, Shkotovo distr., Anisimovka, 14.07-06.08.1994 (N. SAVENKOV). In coll. LMNH and in coll. G. BALDIZZONE.

Geographical distribution: Palaearctic: Europe, Russia (Lower Volga), Turkey, Turkmenistan, Iran, Afghanistan.

\section{Coleophora tamesis WATERS, 1929}

Far East of Russia:

$2 \sigma^{\pi}$, Primorskij Kraj, Shkotovo distr., Anisimovka, 19-24.07.1994 (N. SAVENKOv). In coll. LMNH.

Geographical distribution: Palaearctic: Europe, Morocco, Turkey, Caucasus, Jordan, Turkmenistan, Afghanistan, China, Russian Far East.

\section{Coleophora elodella BALDIZZONE \& OKU, 1988}

Far East of Russia:

20 o 17 우, Primorskij Kraj, Shkotovo distr., Anisimovka, 14-31.07.1994 (N. SAVENKOV). In coll. LMNH and in coll. G. BALDIZZONE.

Geographical distribution: Far East of Russia, Korea, Japan. 


\section{Coleophora okuella BALDIZZONE \& SAVENKOV n. sp.}

(figs 16-22)

Description: Wingspan about 9-10 $\mathrm{mm}$. Antenna simple, whitish, without darker annulation. Labial palpus whitish, streaked with greyish-brown; median joint is about 1.5 times as long as diameter of eye, with short ventro-apical tuft; terminal joint about $2 / 3$ length of median joint. Head and thorax creamy white. Forewing creamy-white, slightly streaked yellow along the veins, more markedly towards the apex; cilia creamywhite. Hindwing and cilia whitish. Legs whitish, streaked with greyish along hind tibia externally. Abdomen whitish.

Male genitalia (figs 16-18): Gnathos nearly globular, supported by short dorsal arm of tegumen; tegumen strongly constricted just above the middle, bowl-shaped, the ventral arms long, being slightly expanded just in the middle part; transtilla rather narrow, nearly horizontal; valva large, dilated apically with rounded ventro-terminal margin; valvula small, very narrow, bristled; sacculus short, but very wide, strongly sclerotized; a strong hornlike projection arising from ventro-caudal end of sacculus and another shorter one from dorso-terminal angle of sacculus, slightly hooked at the apex; phallotheca robust, its prongs being almost the same in length, curved at the apex; cornuti 2-3 in number, different in length, forming a compact bundle.

Female genitalia (figs 20-21): Papilla analis narrow; apophysis posterioris about twice as long as apophysis anterioris; subgenital plate slightly longer than broad, trapezoidal; infundibulum bowl-shaped, widest both at posterior $3 / 4$ and caudally, strongly sclerotized; ductus bursae narrow, spiculated on $1 / 3$ length just after infundibulum; bursa copulatrix small, semi-oval; signum short but robust, horn-like, slightly curved, with small basal dilation.

Structure of abdominal supports (figs 19,21): The $1^{\text {st }}$ tergite with pair of rows of several spinelets in males and none in females; both proximal and distal folds of caudal rib narrow and strong; patches of spinelets in the following tergites rather compact, with 8-13 spinelets on each of the following 2-4 pairs.

Holotype: o (GP BLDZ 11 580), Far East of Russia, Primorskij Kraj, Shkotovo distr., Anisimovka, 29.07.1994 (N.SAVENKOV), in coll. LMNH.

Paratypes: 2 \%, same locality, same collector, in coll. LMNH:

1 우 (GP BLDZ 11 706), 20.07.1994; 1 우, 29.07.1994.

Bionomics: The foodplant and the early stages are not known, but according to the systematic position of the species, it is possible that larva breed on some Juncus or Lurula species.

Distribution: Far East of Russia (Primorskij Kraj).

Remarks: The species belongs to the $30^{\text {th }}$ species-group of ToLL's (1952) system. Male genitalia resemble those of C. maritimella NEX'MAN, 1873 and C. elodella BALDIZZONE \& OKU, 1988, differing, however, by the shape of ventro-caudal process and structure of the phallotheca. In the female genitalia C. okuella shows no close similarity, and the bowlshaped infundibulum readily distinguishes it from related species. 
Etymology: the species is named in the honour of Dr. TosHo OKU, well known Japanese entomologist, an active investigator of Japanese Coleophoridae.

\section{Coleophora therinella (TENGSTRÖM, 1848)}

Far East of Russia:

10 o, 14 우, Primorskij Kraj, Shkotovo distr., Anisimovka, 20.07-07.08.1994 (N. SAVENKOV). In coll. LMNH.

Geographical distribution: Palaearctic: Europe, Russia (Lower Volga), Korea.

\section{Coleophora versurella ZELLER, 1849}

Far East of Russia:

2 đ, Primorskij Kraj, Hasan distr., Bamburovo, 15.08 .1990 (A. NAPOLOv);

19 ơ, 55 우, Primorkkij Kraj, Shkotovo distr., Anisimovka, 20.07-07.08.1994 (N. SAVENKOV). In coll. LMNH.

1 , Primorskij Kraj, Anisimovka, Sukhodol river, $50 \mathrm{~km}$ SE Artyom, 43.1N 132.5E, 0610.08.1993 (C. KUTZSCHER). In coll DEI.

Geographical distribution: Palaearctic: Widely distributed over the entire Palaearctic region. - Nearctic: U.S.A., Canada (introduced). - Neotropical: Argentina, Chile (introduced).

\section{Coleophora vestianella (LINNAEUS, 1758)}

Far East of Russia:

7 đ, 13 ㅇ, Primorskij Kraj, Hasan distr., Bamburovo, 12-23.08.1990 (A. NAPOLOV);

2 o, Primorskij Kraj, South Sikhote Alin', Yasnoye, 29.08.1991 (A. NAPOLOV);

19 o, 11 o , Primorskij Kraj, Shkotovo distr., Anisimovka, 28.07-07.08.1994 (N. SAVENKOV). In coll. LMNH.

Geographical distribution: Palaearctic: Europe, Turkey, Iran, Afghanistan, China, Japan.

\section{Coleophora sternipennella (ZETTERSTEDT, 1839)}

Far East of Russia:

14 o, 19 ㅇ, Primorskij Kraj, Hasan distr., Bamburovo, 12-23.08.1990 (A. NAPOLOv); 44 o, 55 o , Primorskij Kraj, Shkotovo distr., Anisimovka, 28.07-07.08.1994 (N. SAVENKOV). In coll. LMNH.

10 , Primorskij Kraj, Ryazanovka, Boisman inlet, $15 \mathrm{~km}$ SW Slavyanka, 45.5N 131.2E, 12-17.08.1993 (C. KUTZSCHER). In coll. DEI.

Geographical distribution: Palaearctic: Europe, Caucasus, Russia (Lower Volga), Western Siberia, Japan, Korea. 
Coleophora cristata BALDIZZONE, 1989

Female genitalia: (figs 23-25)

Far East of Russia:

$4 \sigma^{\star}, 5$ 옹, Hasan distr., Bamburovo, 15-23.08.1990 (A. NAPOLOV);

$1 \sigma^{\star}$, Primorskij Kraj, Shkotovo distr., Anisimovka, 08.08.1994 (N. SAVENKOV). In coll. LMNH and in coll. G. BALDIZZONE.

Additional material: 1 ㅇ, Japan, Honsyû-Kinki, Iwawaki-san, 16.09.1950 (S. ISSIKI). In coll. G. BALDIZZONE.

Geographical distribution: Palaearctic: China, Korea, Japan, Russian Far East.

New for Japan!

\section{Coleophora kamchatica ANIKIN, 2000}

Recently described by ANIKIN (2000). Male genitalia (figs 26-31).

Far East of Russia:

12 o, Primorskij Kraj, Hasan distr., Bamburovo, 15-23.08.1990 (A. NAPOLOv). In coll. LMNH and in coll. G. BALDIZZONE.

Geographical distribution: Far East of Russia (Kamchatka, Primorskij Krai).

\section{Coleophora hsiaolingensis TOLL, 1942}

Far Fast of Russia:

$3 \sigma^{7}, 1$ q, Primorskij Kraj, Hasan distr., Bamburovo, 17-23.08.1990 (A. NAPOLOV);

10 , 2 ㅇ, Primorskij Kraj, Hasan distr., Yasnoye, 29.08.91 (A. NAPOLOV);

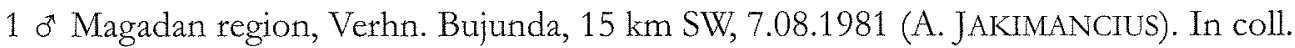
LMNH and in coll. G. BALDIZZONE.

Geographical distribution: China, Japan, Far East of Russia.

Coleophora kudrosella BALDIZZONE \& OKU, 1988

Fat East of Russia:

1 q, Primorskij Kraj, Shkotovo distr., Anisimovka, 5.08.1994 (N. SAVENKOV). In coll. G. BALDIZZONE.

Geographical distribution: Far East of Russia, Japan. 
Coleophora attemisicolella BRUAND, 1855

Far East of Russia:

$20^{\star}, 1$ \& , Hasan distr., Bamburovo, 15-17.08.1990 (A. NAPOLOV). In coll. LMNH;

1 of, Primorskij Kraj, Ryazanovka, Boisman inlet, $15 \mathrm{~km} \mathrm{SW}$ Slavyanka, 45.5N 131.2E, 12-17.08.1993 (C. KUTZSCHER). In coll. DEI.

Geographical distribution: Transpalaearctic.

\section{Coleophora falkovitshella VIVES, 1984}

The species was described by M. FALKOVITSH (1975) from Mongolia on the base of one male under the name Coleophora cornutella. Later VIVES MORENO (1984) recognized that this name was preoccupied and renamed it. Here we describe the previously unknown female.

Female genitalia: (figs 32-34): Papilla analis small; apophysis posterioris about 2.3 times as long as apophysis anterioris; subgenital plate semitrapezoidal, slightly wider than long, caudally deeply cleft by ostium bursae to about half its length, the caudal margin oblique and smooth, with solitary setae; infundibulum with almost parallel sides, about twice as long as wide; ductus bursae spiculate in the initial $1 / 4$, heavily sclerotized in the next $1 / 4$, then transparent; bursa copulatrix small, drop-shaped; signum curved horn-like with semi-ovate dilation.

Far East of Russia:

31 o, 99 o (GP BLDZ 11 689), Primorskij Kraj, Shkotovo distr., Anisimovka, 23.0707.08.1994 (N. SAVENKOV). In coll. LMNH and in coll. G. BALDIZZONE.

Additional material: $1 \delta^{\star}$, Japan, Honshu, Morioka, 31.07.1966 (T. OKU). In coll. LIE. Geographical distribution: Mongolia, Far East of Russia, Japan.

New for Japan!

\section{Coleophora gardesanella ToLt, 1953}

Far East of Russia:

1 o, Primorskij Kraj, Shkotovo distr., Anisimovka, 17.07.1994 (N. SAVENKOV). In coll. G. BALDIZZONE.

Geographical distribution: Palaearctic (Europe, Far East of Russia).

New for Asia!

Coleophora trochilella (DUPONCHEL, 1843)

Far East of Russia:

2 \&, Primorskij Kraj, Shkotovo distr., Anisimovka, 19.07-03.08.1994 (N. SAVENKOV). In coll. LMNH. 
The Far East specimens differ from European ones by the almost unicolorous forewing, which is caused by the reduction of light streaks. However, no differences in genitalia were found.

Geographical distribution: Palaearctic (Europe, Far East of Russia).

New for Asia!

Coleophora linosyridella FUCHS, 1880

Far East of Russia:

1 o $^{\star}$, Primorskij Kraj, Shkotovo distr., Anisimovka, 26.07.1994 (N. SAVENKOV). In coll. G. BALDIZZONE.

Additional material: 20 , J, Sotoyama, Iwate, Honshu, 16.07.1971, e.l. Aster glehinii var. bondoensis (T. OKU); 1 o Japan, Shimamatsu, Hokkaido, 3.07.1963, e.l. Aster scaber (T. OKU). In coll. G. BALDIZZONE.

Geographical distribution: Palaearctic: Europe, Japan.

New for Asia!

Coleophora raphidon BALDIZZONE \& SAVENKOV n. sp.

(figs 35-38)

Description: Wingspan about $10 \mathrm{~mm}$. Antenna simple; annulation more or less distinct to about 3/5, apically without annulation, whitish. Labial palpus cream-whitish; median joint streaked with brownish externally, about twice as long as diameter of eye; terminal joint lost. Head and thorax cream-ochreous. Forewing ochreous-brown, streaks along wing margins and veins distinct, the costal and median ones being broader; cilia creambrownish. Hindwing and cilia brownish-grey. Legs whitish, streaked with dark-brown along tibia and tarsi externally.

Female: Unknown.

Male genitalia (figs 35-37): Gnathos semiovate; tegumen rather narrow, with both dorsal and ventral arms moderately long; transtilla robust, hook-like, strongly curved dorsally, with tips orientated ventrally; valva rather large, semi-ovate; valvula narrow, more bristled in the middle; sacculus elongate subtriangular, its heavily sclerotized terminal end forming a large blunt process with rounded tip; a long and arcuate dorsal projection arising from midpart of sacculus to form a semicircle together with the upper margin of sacculus; phallotheca long and slender, slightly curved, asymmetrically bifurcate, both prongs are pointed at the tip, without any teeth, the shorter prong is about $4 / 5$ of the longer one; cornutus rather small, elongate.

Structure of abdominal supports (fig. 38): The $1^{\text {st }}$ tergite with a pair of rows, 7-12 spinelets in each; proximal fold of caudal rib narrow, curved distally, strong, gradually atrophying towards both ends, distal fold rather strong at both ends, but much atrophied centrally; paired patches of spinelets in the following tergites very narrow, about 4 times longer than wide, composed of 20-24 spinelets. 
Holotype: $\sigma^{+}$(GP BLDZ 11 611), Far East of Russia:, Primorskij Kraj, Shkotovo distr., Anisimovka, 05.08.1994 (N.SAVENKOV), in coll. LMNH.

Bionomics: The foodplant and the early stages are not kown.

Distribution: Far East of Russia (Primorskij Kraj).

Remarks: The species belongs to the $30^{\text {th }}$ species group of TOLL's (1952) system, trocbilella (DUPONCHEL, 1843)-section. The structure of the male genitalia resembles many species of this group: calandrella BALDIZZONE, 1982, ribasella BALDIZZONE, 1982, cinclella BALDIZZONE \& OKU, 1990, tamara BALDIZZONE, 1994, ispartae BALDIZZONE, 1994, yushongensis LI \& ZHENG, 2000, linosyridella FUCHS, 1880. The basic differences are in the structure of phallotheca.

Etymology: The species is named from two greek words, @ópis (= needle) and ódoús (= tooth) because of the shape of the phallotheca apex.

\section{Coleophora irinae BALDIZZONE \& SAVENKOV n. sp.}

(figs 39-42)

Description: Expanse about $9 \mathrm{~mm}$. Antenna simple, whitish, without darker annulation. Labial palpi whitish; medial joint streaked with brownish externally, about 1.5 times as long as diameter of eye, with a very short ventro-apical tuft; terminal joint about $2 / 3$ as long as medial joint. Head and thorax brownish-grey. Forewing greyish-brown; streaks along veins (except the margin) rather indistinct; dark greyish-brown scales scattered over whitish spaces, some of them confluent to form three indistinct streaks; cilia brownish-grey. Hindwing and cilia brownish-grey. Legs cinereous-white, streaked with dark brownish-grey along tibia and tarsi externally.

Female: Unknown.

Male genitalia (figs 39-41): Gnathos semiovate; tegumen small, somewhat trapezoidal, with rather short dorsal and ventral arms; transtilla hornlike, gradually narrowed towards the tip; valva moderately large, with almost parallel margins; valvula small and narrow, bristled; sacculus subtriangular, with terminal process narrow and rounded at the tip; a long and slightly arcuate dorsal projection arising from midpart of sacculus; phallotheca rather long, curved, with a process at the top curved backwards at almost half of the length of phallotheca; cornutus - a long spine.

Abdominal tergites (fig. 42): The $1^{\text {st }}$ tergite with a pair of elongate rows about 15 spinelets in each; proximal fold of caudal rib narrow, curved distally, very strong, distal fold strong on both ends, but much atrophied centrally; paired patches of spinelets on the following tergites are much more compact, elongate (about 6 times longer then wide), slightly curved, composed of more than 30 spinelets.

Holotype: $\sigma^{*}$ (GP BLDZ 11566), Far East of Russia, Primorskij Kraj, Shkotovo distr., Anisimovka, 26.07.1994 (N.SAVENKOV), in coll. LMNH.

Bionomics: The foodplant and the early stages are not known.

Distribution: Far East of Russia (Primorskij Kraj). 
Etymology: The species is named after the first name of IRINA SAVENKOVA, the wife of the junior author.

Remarks: The species belongs to the 30th species-group of TOLL's (1952) system, a bit similar to C. bornicensis FUCHS, 1886. The shape of the sacculus and especially the peculiar structure of the phallotheca readily separate the new species.

Coleophora expressella KLEMENSIEWITCH, 1902

Far East of Russia:

6 ㅇ, Primorskij Kraj, Shkotovo distr., Anisimovka, 03-08.08.1994 (N. SAVENKOV). In coll. LMNH.

Geographical distribution: Palaearctic: Italy, Central and Northern Europe, China.

Coleophora heihensis LI \& ZHUNG, 2000

Far East of Russia:

1 ơ, 7 ㅇ, Primorskij Kraj, Shkotovo distr., Anisimovka, 03-07.08.1994 (N. SAVENKOV). In coll. LMNH and in coll. G. BALDIZZONE.

Geographical distribution: China, Far East of Russia.

\section{Coleophora striatipennella NYLANDER in TENGSTRÖM, [1848]}

Far East of Russia:

1 ㅇ, Primorskij Kraj, Shkotovo distr., Anisimovka, 01.08.1994 (N. SAVENKOv). In coll. LMNH.

Geographical distribution: Transpalaearctic.

New for Asia!

Coleophora parki BALDIZZONE \& SAVENKOV n. sp. (figs 43-50)

Description: Wingspan about $9 \mathrm{~mm}$. Antenna simple, creamy-white, without darker annulation. Labial palpus creamy-white, streaked with greyish-brown externally; medial joint about 1.5 times as long as diameter of eye, with very short ventro-apical tuft; terminal joint slightly shorter than medial joint. Head and thorax pale ochreous-white. Forewing whitish, streaked ochreous-brownish along veins and scattered with deep brown scales; cilia brownish-grey. Hindwing grey; cilia brownish-grey. Legs creamy-white, with darkbrown median streak along hind tibia externally.

Male genitalia (figs 43-46): Gnathos globular; tegumen narrow, cup-shaped, supported by long ventral arms; transtilla narrow, inverted $v$-shaped; valva rather large, with almost parallel margins; valvula semiovate, bristled; sacculus strong, narrowed towards the long 
horn-like process at terminal end, armed with small additional tooth; phallotheca strong, asymmetrical, with very long caulis forming two curved branches; one of the prongs being longer, strongly curved backwards at almost half of the prong's length, and the other much shorter, slightly curved apically; cornutus thorn-like.

Female genitalia (figs 48-50): Papilla analis small, rather narrow; apophysis posterioris about 3 times as long as apophysis anterioris; subgenital plate semitrapezoidal, the caudal margin deeply cleft by spatulate ostium bursae at caudal end; infundibulum cup-shaped, with funnel-like ostium; ductus bursae transparent with weakly spiculate entrance; bursa copulatrix small; signum curved horn-like, with semiovate basal dilation.

Structure of abdominal supports (fig. 47): The 1st tergite with patches of 6-7 spinelets each; proximal fold of caudal rib very narrow, but rather strong, distal fold rather strong at both ends, slightly atrophying centrally; paired patches of spinelets in the following tergites narrow, about 3 times as long as wide, composed of 18-22 spinelets.

Holotype: $\sigma^{*}$ (GP BLDZ 11 701), Far East of Russia, Primorskij Kraj, Shkotovo distr., Anisimovka, 28.07.1994 (N.SAVENKOV), in coll. LMNH.

Paratypes: 10 o, 13 i

2 ơ, 13 \% :

$10^{\pi}, 2$ ㅇ, same locality, same collector, in coll. LMNH:

1 ơ, 05.08.1994; 1 i (GP BLDZ 11 612), 07.08.1994; 1 ㅇ (GP BLDZ 11 702), 03.08.1994; 5 ㅇ, (GP PARK 1962, 1965, GP BlDZ 10964, 10984, 11013), S Korea, Pyongchang, GW, 31.07.1991. In coll. PARK and in coll. BALDIZZONE;

1 o (GP BLDZ 11014), S Korea, Hongcheon, Naemyeon, 14.08.1987, coll. PARK;

1 o, 4 o (GP PARK 1984 male, GP PARK 1973, GP BLDZ 10961, 10969, 11019 females), S Korea, Chuncheon, 12.08.1988, coll. PARK and in coll. BALDIZZONE;

1 \& (GP BLDZ 11642), Far East of Russia:, Primorskij Kraj, Severnaja inlet, 9 km N Slavjanka, 42.9N 131.5E, 10 m, 12-15.08.1993 (C. KUTZSCHER). In coll. DEI;

$80^{*}$, leg. JALAVA, KULLBERG \& KAARE, in coll. ZMH and J. TABELL:

$60^{\circ}$ (GP JT 3227), S. Primorje 43 38’N 132 33’E, Ussuriskij Res. 250m, 29.-31.7.1998;

$10^{\star}$, S. Primorje $42^{\circ} 37^{\prime} \mathrm{N} 131^{\circ} 08^{\prime} \mathrm{E}$, Andreevka 10.-15.8.1998;

$10^{\star}$, S. Primorje $44^{\circ} 2^{\prime} \mathrm{N} 134^{\circ} 12^{\prime} \mathrm{E}, \mathrm{V}$. Ussuriskij $550 \mathrm{~m}$, biol. st. Berezovyi sok., 31.7.5.8.1998.

Bionomics: The foodplant and the early stages are unknown.

Distribution: Far East of Russia (Primorskij Kraj), S Korea.

Remarks: The systematic position of the species is unclear, possibly it is isolated. In the male genitalia unusually long branches of the caulis together with the structure of the phallotheca make the determination of the species unmistakable. In the female genitalia there is a slight similarity with C. striatipennella NYLANDER in TENGSTRÖM, [1848], from which it is distinguished by the absence of spiculation in the ductus bursae and different form of the subgenital plate.

Etymology: the species is named after Prof. KIU TEK PARK, the well known South Korean lepidopterologist. 
Coleophora artemisiella SCOTT, 1861

Far East of Russia:

9 o, 9 o, Primorskij Kraj, Shkotovo distr., Anisimovka, 13.07-05.08.1994 (N. SAVENKOV). In coll. LMNH.

Geographical distribution: Transpalaearctic.

\section{Coleophora argentula (STEPHENS, 1834)}

Far East of Russia:

1 o, Primorskij Kraj, Hasan distr., Bamburovo, 17.08.1990 (A. NAPOLOV). In coll. LMNH. Geographical distribution: Transpalaearctic.

\section{Coleophora granulatella ZELLER, 1849}

Far East of Russia:

1 o, Primorskij Kraj, Shkotovo distr., Anisimovka, 03.08.1994 (N. SAVENKOV). In coll. LMNH.

Geographical distribution: Palaearctic: Europe, Russia (Lower Volga), Turkmenistan, Mongolia.

\section{Coleophora adspersella BENANDER, 1939}

Far East of Russia:

$1 \sigma^{*}$, Primorskij Kraj, Hasan distr., Bamburovo, 17.08.1990 (A. NAPOLOV). In coll. LMNH. Additional material: 1 o 1 \&, Japan, Utatsu, Miyasi-ken, Honshu, e.l. 10.08.1981 (T. OKU). In coll. BALdizzONE; 1 \%, S Korea, Chuncheon, 14.08.1987 (K. T. PARK). In coll. PARK.

Geographical distribution: Palaearctic: Europe, Russia (Lower Volga and Far East), China, Japan, Korea.

\section{New for Japan and Korea!}

\section{Coleophora silenella HERRICH-SCHÄFEER, 1855}

The difficulties with the identification and status of many silenella-complex species are well-known. Some attempts were made by H. PATZAK (1976) to solve these problems in European species. Although there are some differences in male and female genitalic structures between our East Asiatic specimens and European, we leave this taxon under the name of $C$. silenella.

Male genitalia (fig. 51), female genitalia (figs 52-53). 
Far East of Russia:

6 ơ, Primorskij Kraj, Hasan distr., Bamburovo, 12-17.08.1990 (A. NAPOLOV);

$60^{\star}, 4$ q, Primorskij Kraj, Shkotovo distr., Anisimovka, 30.07-07.08.1994 (N. SAVENKOV). In coll. LMNH and in coll. G. BALDIZZONE;

$5 \mathrm{o}^{\star}$, Primorskij Kraj, Ryazanovka, Boisman inlet, $15 \mathrm{~km}$ SW Slavyanka, 45.5N 131.2E, 12-17.08.1993 (C. KUTZSCHER). In coll. DEI.

\section{Coleophora napolovi BALDIZZONE \& SAVENKOV n. sp.}

(figs 54-57)

Description: Wingspan about $12 \mathrm{~mm}$. Antenna simple, whitish, with very indistinct annulation. Labial palpus cinereous-white; medial joint widely, but indistinctly streaked with greyish-brown externally, about 1.5 times as long as diameter of eye, with a very short ventro-apical tuft; terminal joint half as long as medial joint. Head and thorax dark greyish-ochreous. Forewing dark brownish-grey, with some diffused darker scales; cilia same coloured as wing surface. Hind wing and its cilia dark brownish-grey. Legs cinereouswhite, streaked with dark brownish-grey along tibia and tarsi externally.

Female: Unknown.

Male genitalia (figs 54-56): Gnathos globular; tegumen nearly trapezioidal, suppoted by rather long ventral arms; transtilla narrow, but strongly sclerotized; valva semiovate; valvula rather broad, bristled; sacculus long and broad, terminal angle with wide and blunt process, two processes are on the ventral part, the longest one reaches the costa of valva; phallotheca long, with asymmetrical branches, one of which is slightly longer, armed with two teeth near the top and additional long process, the shorter branch with strong tooth just at the middle; cornutus - a long spine.

Structure of abdominal supports (fig. 57): The $1^{\text {st }}$ tergite with a pair of rows of about 30-32 spinelets each, the caudal rib having narrow, but distinct proximal fold and strong distal; paired patches of spinelets in the following tergites rather compact, about three times longer then wide.

Holotype: $0^{*}$ (GP BLDZ 11590), Far East of Russia, Primorskij Kraj, Hasan distr., Bamburovo, 23.08.1990 (A. NAPOLOV), in coll. LMNH.

Bionomy: The foodplant and the early stages are unknown.

Distribution: Far East of Russia (Primorskij Kraj).

Remarks: The species belong to the $30^{\text {th }}$ species-group of TOLL's (1952) system. The male genitalia show an affinity to C. barbaricina BALDIZZONE, 1980, with obvious differences regarding the external margin of sacculus and the structure of the phallotheca. Etymology: the species is named after ALEXANDR NAPOLOV, latvian entomologist, collector of the holotype. 
Coleophora unipunctella ZELLER, 1849

Far East of Russia:

7 ơ, 7 9 , Primorskij Kraj, Shkotovo distr., Anisimovka, 27.07-06.08.1994 (N. SAVENKOV). In coll. LMNH.

Geographical distribution: Palaearctic: Spain, France, Italy, Central Europe, Lithuania, Russia (Lower Volga).

New for Asia!

Coleophora clypeiferella HOFMANN, 1871

Far East of Russia:

$20^{\star}, 4$ ㅇ, Primorskij Kraj, Hasan distr., Bamburovo, 15-23.08.1990 (A. NAPOLOV). In coll. LMNH.

Additional material: 1 đ J Japan, Tenno, Akita Pref., 18.09.1969 (T. OKU). In coll. BALDIZZONE.

Geographical distribution: Palaearctic: Europe, Russia (Lower Volga), Caucasus, China, Japan. New for Japan!

Coleophora squalorella ZELLER, 1849

Far East of Russia:

2 o $^{\star}$, Primorskij Kraj, Hasan distr., Bamburovo, 23.08 .1990 (A. NAPOLOV). In coll. LMNH. Geographical distribution: Palaearctic: Western, Central and Northern Europe, Baltic States, Russia (Lower Volga and Far East), China.

Coleophora weymarni TOLL, 1942

(figs 58-65)

Far East of Russia:

1 o, 4 ㅇ, Primorskij Kraj, Spassk distr., Prohori, 22.07 .1989 (A. NAPOLOV);

2 o, 3 o, Primorskij Kraj, Shkotovo distr., Anisimovka, 20.07-06.08.1994, N. SAVENKOV. In coll. LMNH and in coll. G. BALDIZZONE.

Geographical distribution: China, Far East of Russia.

\section{Coleophora lativittella ERSCHOFF, 1877}

(figs 66-73)

The species was described from the vicinity of Irkutsk (Siberia, Russia). Its genitalic structures remained unstudied; they are described here for the first time. 
Male genitalia (figs 66-68): Gnathos small, semiovate; tegumen long and narrow, with both dorsal and ventral arms long; transtilla rather broad, robust, strongly sclerotized; valva moderately large and long, strongly dilated apically with rounded ventro-terminal margin; valvula broad suboblong and bristled; sacculus narrow and long, about 4 times as long as wide, strongly sclerotized, with two acute horn-shaped strongly sclerotized projections at the dorso-terminal edge, the dorsal projection is about 1.5 times as long as the slightly curved ventral one; aedoeagus moderately long, its prongs being the same in length; cornuti small and numerous, situated in two groups differing in number.

Female genitalia (figs 70-72): Papilla analis small and weakly sclerotized; apophysis posterioris about twice as long as apophysis anterioris, all very long; subgenital plate slightly wider than long, semitrapezoidal, the caudal margin set with long setae and deeply excavated with funnel-shaped ostium bursae almost at one half of subgenital plate's length; infundibulum narrow; ductus bursae very long, spirally turned in four revolutions, initial half being passed through by an internal strand and strongly spiculated in most of its length, while terminal half is dotted with spinelets for most of its length, gradually widening towards bursa copulatrix; bursa copulatrix semiovate; signum strong, hooklike, semiovate basal plate with two markings.

Structure of abdominal supports (figs 69,73 ): The $1^{\text {st }}$ tergite with confluent field of spinelets of about 200 in number, which occupies almost whole central part of tergite; proximal fold of caudal rib narrow, strong, sinuated, slightly atrophying centrally, distal fold narrow, strong, following the proximal fold in sinuation; in the following tergites patches of spinelets are also clearly confluent, becoming slender towards the tip of abdomen.

Far East of Russia:

$10^{\star}$ (GP BLDZ 11 600), Primorskij Kraj, S(outh) Sikhote-Alin', Yasnoye, 28.08.1991,(A. NAPOLOV);

1 o (GP BLDZ 11 558), Primorskij Kraj, Hasan distr., Bamburovo, 23.08.1990, (A. NAPOLOV). In coll. G. BALDIZZONE.

Bionomics: The foodplant and the early stages are unknown.

Distribution: East of Russia (Irkutsk and Primorskij Kraj) and Mongolia.

\section{Acknowledgements}

The authors want to express their thanks to Dr. V. KONONENKO (Vladivostok, Russia) for the help and support of the expedition, Prof. K. PARK (Chuncheon, South Korea), Dr. R. GAEDIKE (Eberswalde, Germany), Dr. P. IVINSKIS (Vilnius, Lithuania) and Mr. A. NAPOLOV (Rīga, Latvia), Mr. J. TABELL for the loan of material. A special thanks to Dr. M. CORLEY (Faringdon, England), for the correction of the English text.

\section{References}

ANIKIN, V. V. 1998: On the casebearer fauna of the Far-East region of Russia (Coleophoridae). - Japan Heterocerist's Journal 200: 424-429, 3 figs.

ANIKIN, V. V. 1999: Two new species of the Coleophoridae (Lepidoptera) from the Far-East region of Russia, with records of a few others. - Japan Heterocerist's Journal 205: 90-91, 7 figs.

BALDIZZONE, G. 1980: Contributions à la connaissance des Coleophoridae XVII. Coleophora barbaricina n. sp. -Alexanor 11 (5): 200-202, 11 figs. 
BALdizzone, G. 1981: Contributions à la connaissance des Coleophoridae, XXII. Nouvelles synonymies dans le genre Coleophora HüBNER (II). - Nota lepidopterologica 4 (3): 63-79, 36 figs.

BALDIZZONE, G. 1989: Contributions to the knowledge of the Coleophoridae. L. Coleophora eurasiatica sp. n. and Coleophora koreana sp. n. - Nota lepidopterologica 12 (1): 13-18.

Baldizzone, G. \& OKU, T. 1988a: Descriptions of Japanese Coleophoridae I. - Tyô to Ga 39 (2): 119-135. Batdizzone, G. \& OKU, T. 1988b: Descriptions of Japanese Coleophoridae II. - Tyô to Ga 39 (3): 207-221. BAldizzone, G. \& OKU, T. 1990a: Descriptions of Japanese Coleophoridae III. - Tyô to Ga 41 (2): 97-112.

BALDIZZONE, G. \& OKU, T. 1990b: Descriptions of Japanese Coleophoridae IV. - Tyô to Ga 41 (3): 155-169. FALKOVITSH, M. I. 1974: Two new east-asiatic species of Coleophoridae (Lepidoptera). - Nasekomye Mongolii 2: 233-237.

FALKOVITSH, M. I. 1975: Ergebnisse der zoologischen Forschungen von Dr. Z. KASZAB in der Mongolei. 325. Neue Arten der Familie Coleophoridae (Lepidoptera). I. - Nasekomye Mongolii 3: 351-369.

FALKOVITSH, M. I. 1976: Results of the zoological explorations of Dr. Z. KASZAB in Mongolia 364. New species of the family Coleophoridae (Lepidoptera). II. - Nasekomye Mongolii 4: 370-380.

FALKOVITSH, M. I. 1977: Ergebnisse der zoologischen Forschungen von Dr. Z. KASZAB in der Mongolei, 422. Neue Arten der Familie Coleophoridae (Lepidoptera). III. - Nasekomye Mongolii 5: 589-605.

FALKOVITSH, M. I. 1979: Ergebnisse der zoologischen Forschungen von Dr. Z. KASZAB in der Mongolei, 438. Neue Arten der Familie Coleophoridae (Lepidoptera). 4. - Nasekomye Mongolii 6: 375-393.

FALKOVITSH, M. I. \& REZNIK, S. YA. 1980: Ergebnisse der zoologischen Forschungen von Dr. Z. KASZAB in der Mongolei, 444. Verzeichniss der Coleophoriden-Arten, (Lepidoptera). - Nasekomye Mongolii 7: 366-377.

OKU, T. 1965: Descriptions of nine new species of the genus Coleophora from Japan, with notes on other species (Lepidoptera, Coleophoridae). - Insecta Matsumurana 27 (2): 114-123.

OKU, T. 1974: Two new species of Coleophora (Lepidoptera, Coleophoridae), feeding on Artemisia in Japan. - Kontyû 42 (3): 33-35.

PARK K.-T. \& BALDIZZONE G. 1992: Systematics of Coleophoridae (Lepidoptera) in Korea. - Korean Journal of Applied Entomology 31 (4): 516-535.

PATZAK, H. 1976: Zur Identität der Arten um Coleopbora silenella HERRICH-SCHÄFFER, 1855. - Deutsche entomologische Zeitschrift, N. F. 23 (1/3): 157-164.

REZNIK, S. YA. 1974: New species of casebearers moths of the group C. astragalella Z. (Lepidoptera, Coleophoridae). - Nasekomye Mongolii 2: 238-249.

REZNIK, S. YA. 1975: New species of casebearers of the group Coleophora vibicella HB. (Lepidoptera, Coleophoridae) from Mongolia. - Nasekomye Mongolii 3: 370-394.

REZNIK, S. Ya. 1977: On the fauna genus Multicoloria CAP. (Lepidoptera, Coleophoridae) of Tuva and Mongolia. - Nasekomye Mongolii 5: 606-614.

ToLL, S. 1942: Studien über die Genitalien einiger Coleophoriden III. - Veröffentlichungen des deutschen Kolonial- und Überseemuseums Bremen 3 (3): 288-299, 22 figs.

ToLL, S. 1952 [1953]: Rodzina Eupistidae (Coleophoridae) Polski.- Materiały do fyziografii kraju., 32: 1-292. TOLL, S. 1953: Eupistidae (Coleophoridae) Polski. - Materiały do fyziografii kraju 32: 1-292.

VIVES MORENO, A. 1984: Nueras adiciones y correciones a la familia Coleophoridae HüBNER, 1825, de España y Portugal. - SHILAP Revista lepidopterologica 12 (47): 253-255.

\section{Author's addresses:}

GIORGIO BALDIZZONE

Via Manzoni 24

14100 Asti

ITALIA
NIKOLAY SAVENKOV

Latvian Museum of Natural History

K.Barona str., 4

Rīga, LV - 1712

LATVIA 
Figure plates:
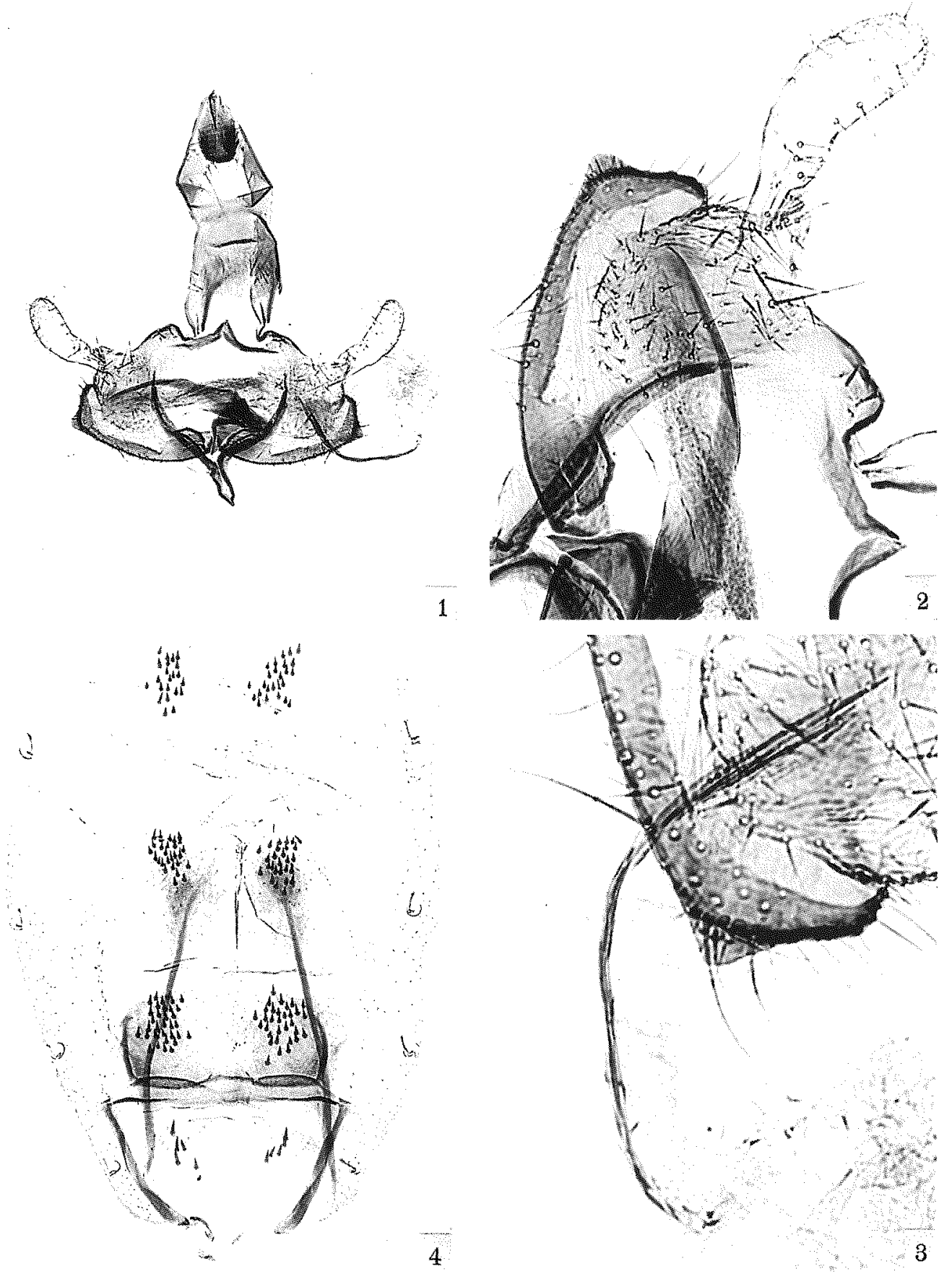

Figs 1-4: Coleophora platyphyllae OKU, o 1. male genitalia (PG BLDZ 11607) "Primorskij Kraj, Shkotovo distr, Anisimovka, 29.07.1994, N. SAVENKOV", 2. detail of genitalia at high magnification, 3. cornuti at high magnification, 4 . abdomen. 


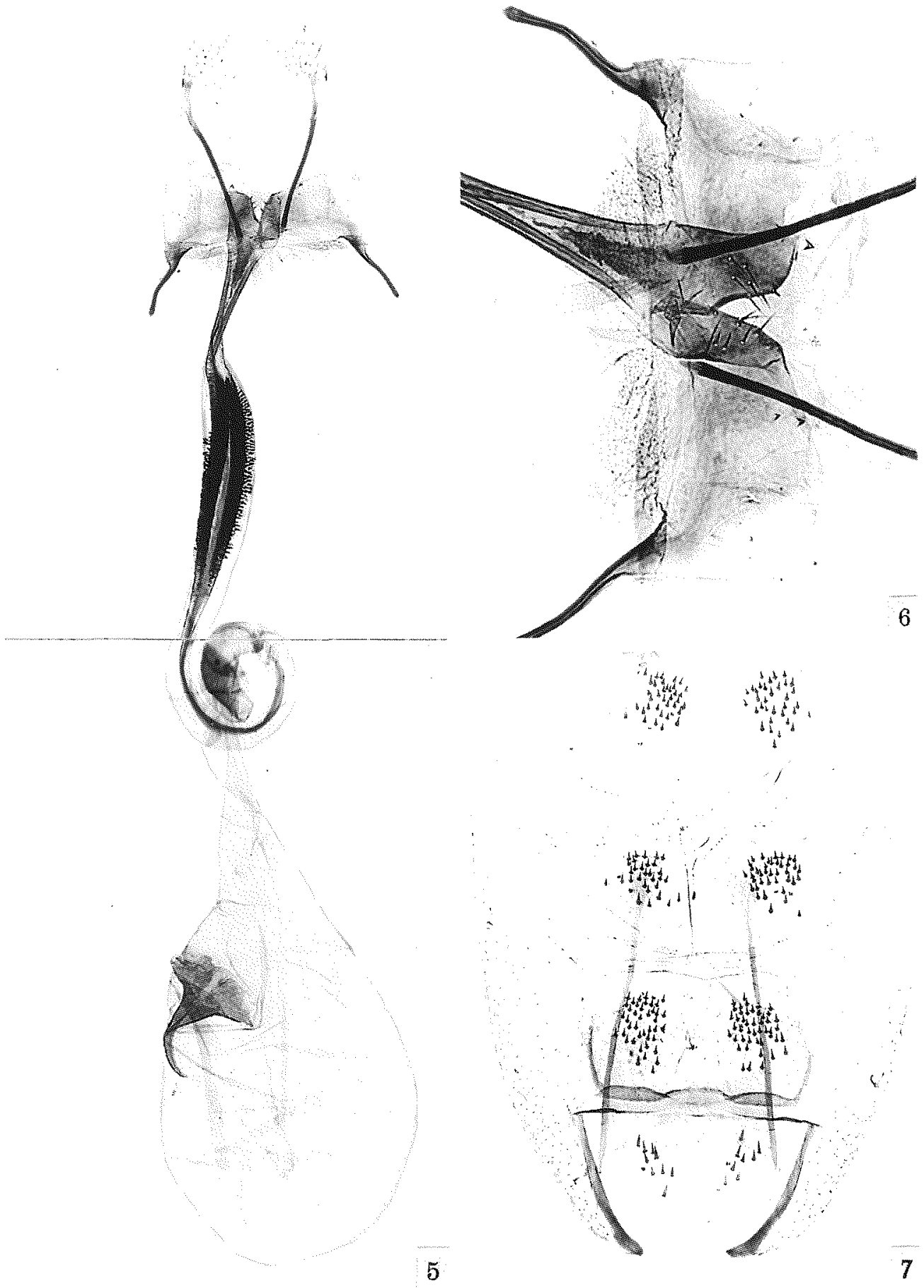

Figs 5-7: Coleophora platyphyllae OKU, o 5. female genitalia (PG BLDZ 11575) "Primorskij Kraj, Shkotovo distr., Anisimovka, 19.07.1994, N. SAVENKOV”, 6. sterigma at high magnification, 7. abdomen. 

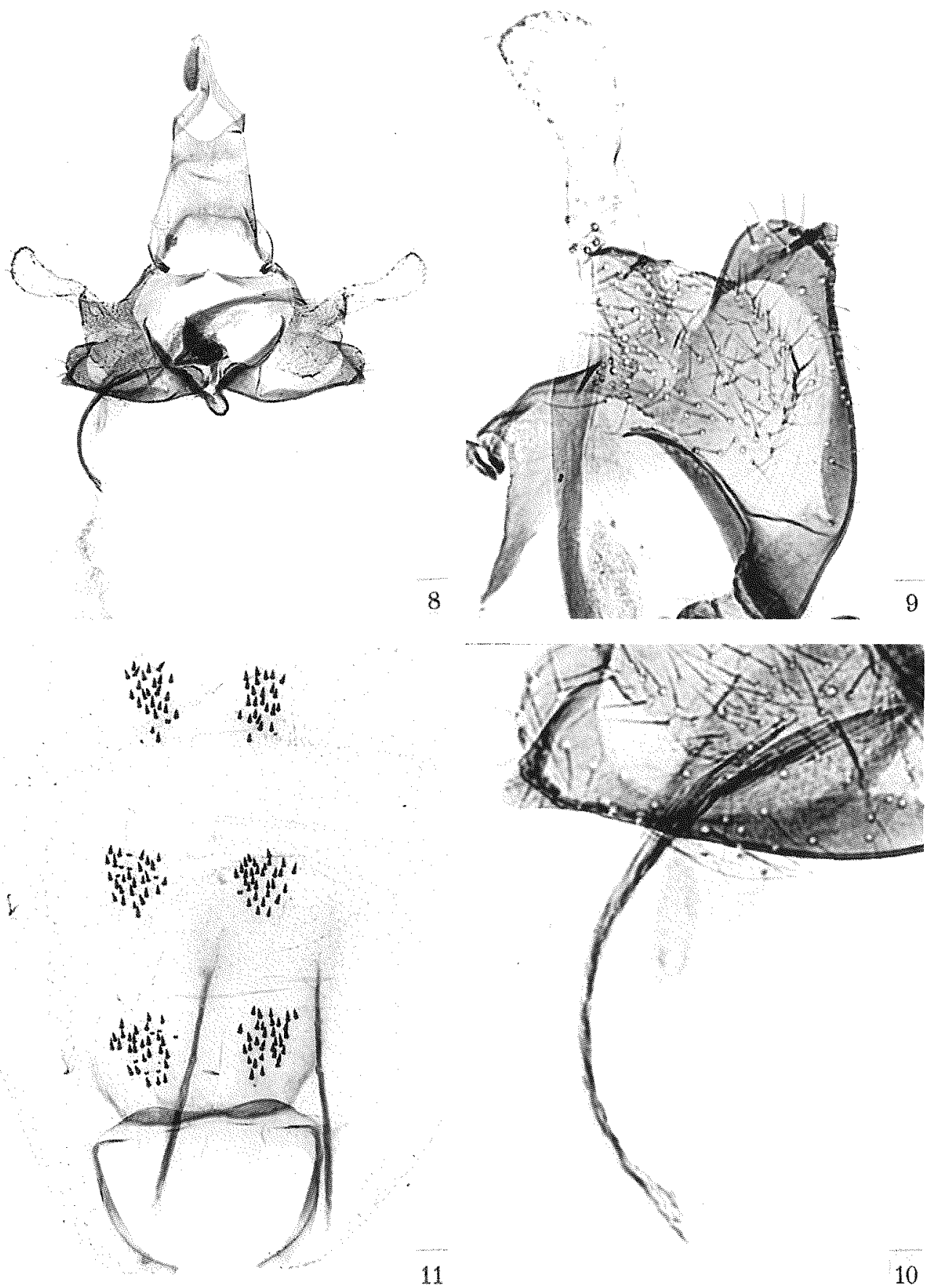

Figs 8-11: Coleaphora teregnathella BALDIZZONE \& SAVENKOV n. sp., o 8. male genitalia (PG BLDZ 11603 - paratype), 9. detail of genitalia at high magnification, 10. cornuti at high magtnification, 11. abdomen. 

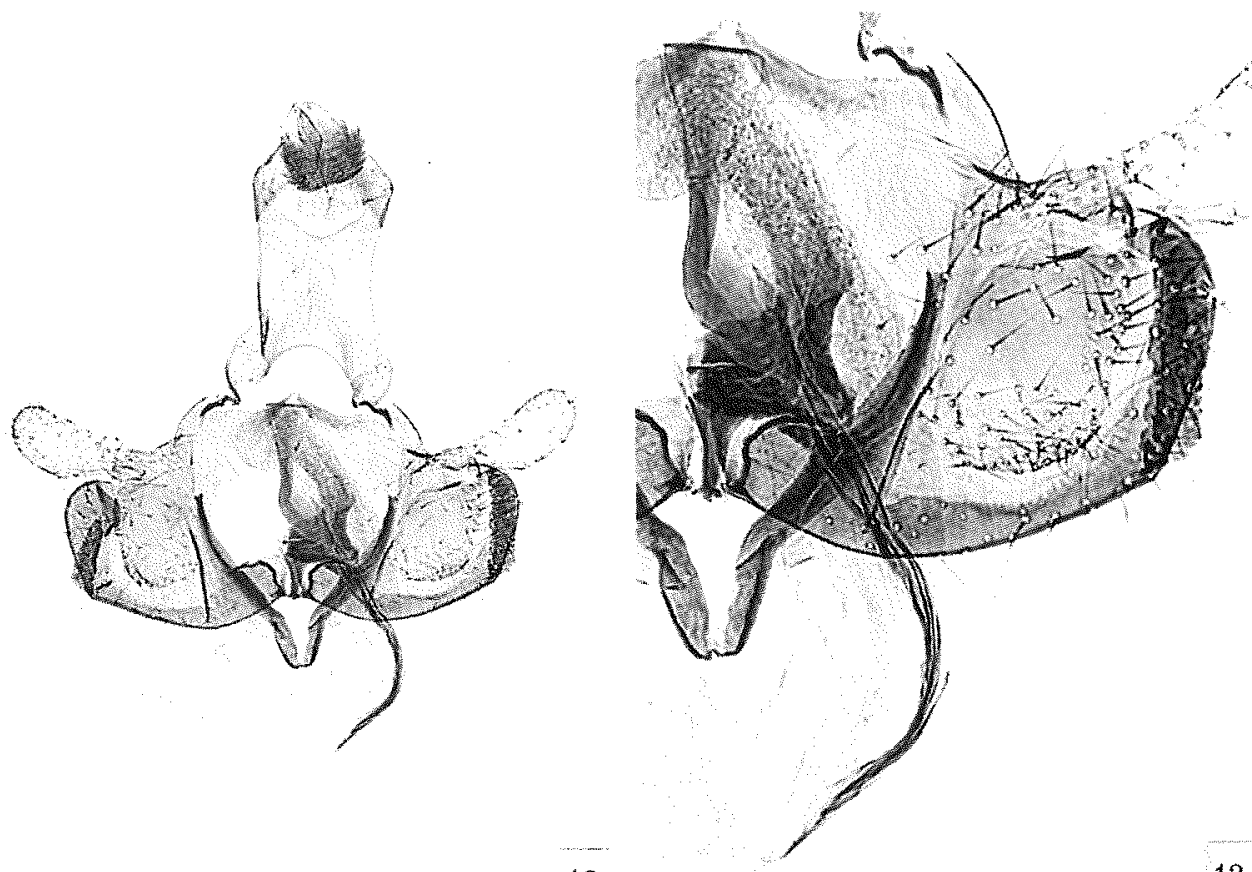

12
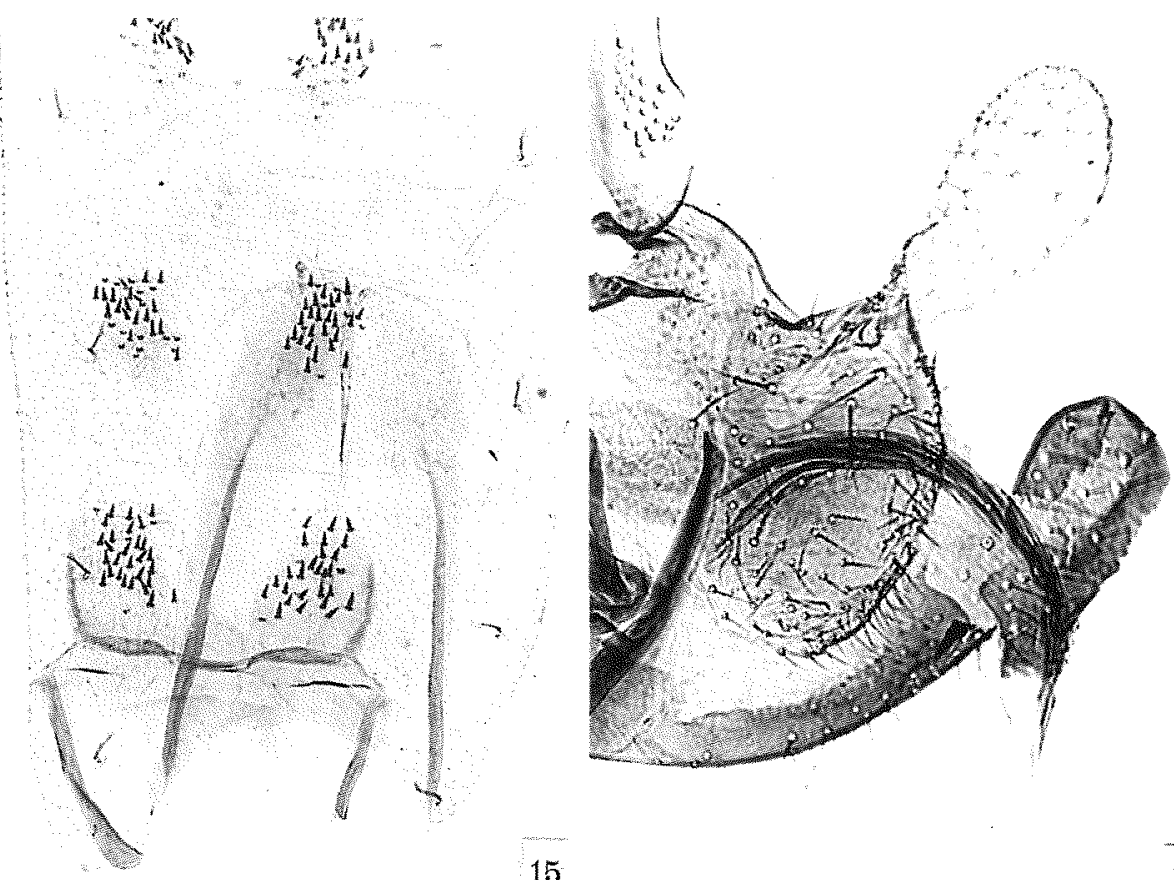

15

Figs 12-15: Coleopthora kononenkoi BALDIZZONE \& SAVENKOV n. sp., o 12. male genitalia (PG BLDZ 11692) - holotype, 13. detail of genitalia at high magnification, 14, cornuti at high magnification (PG BLDZ 11570-paratype), 15. abdomen. 


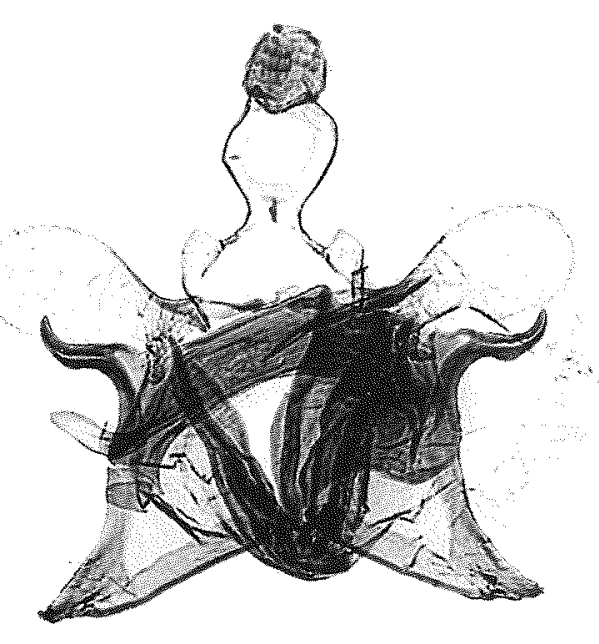

16

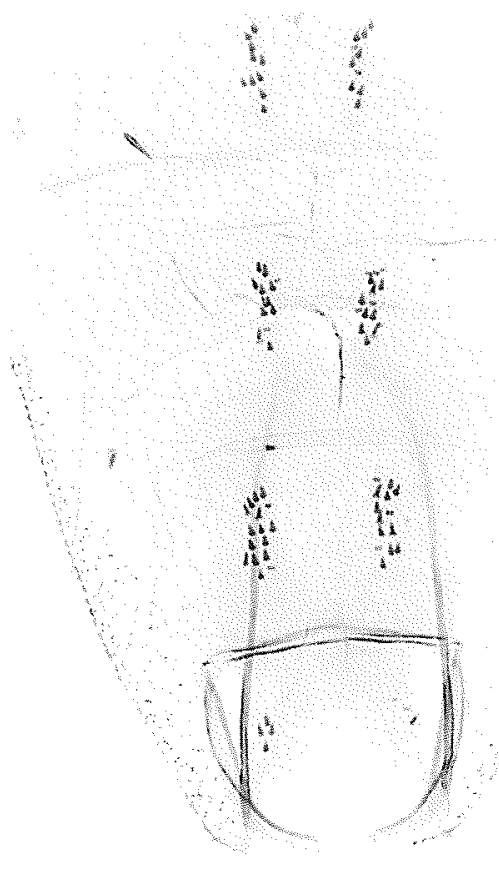

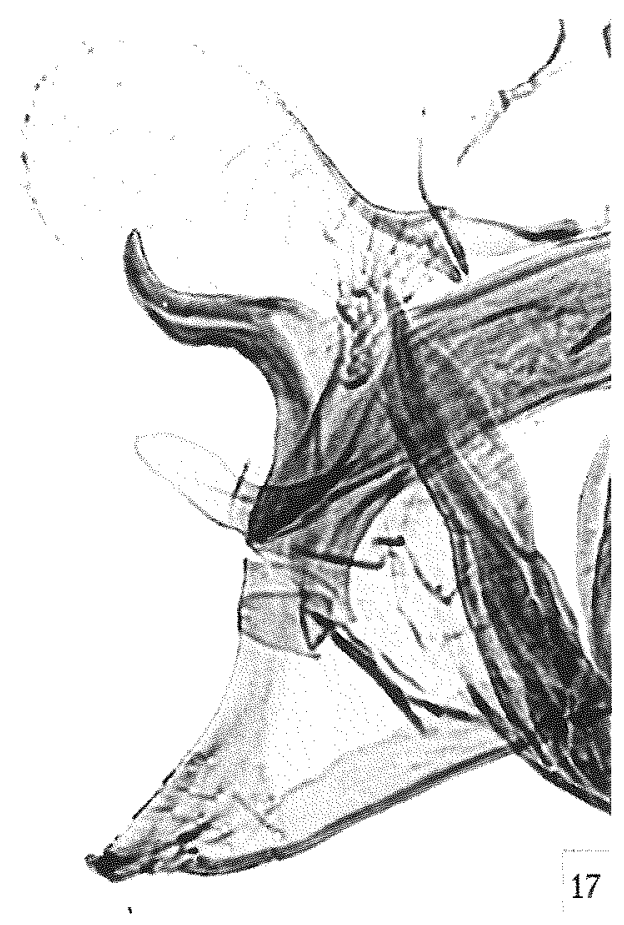

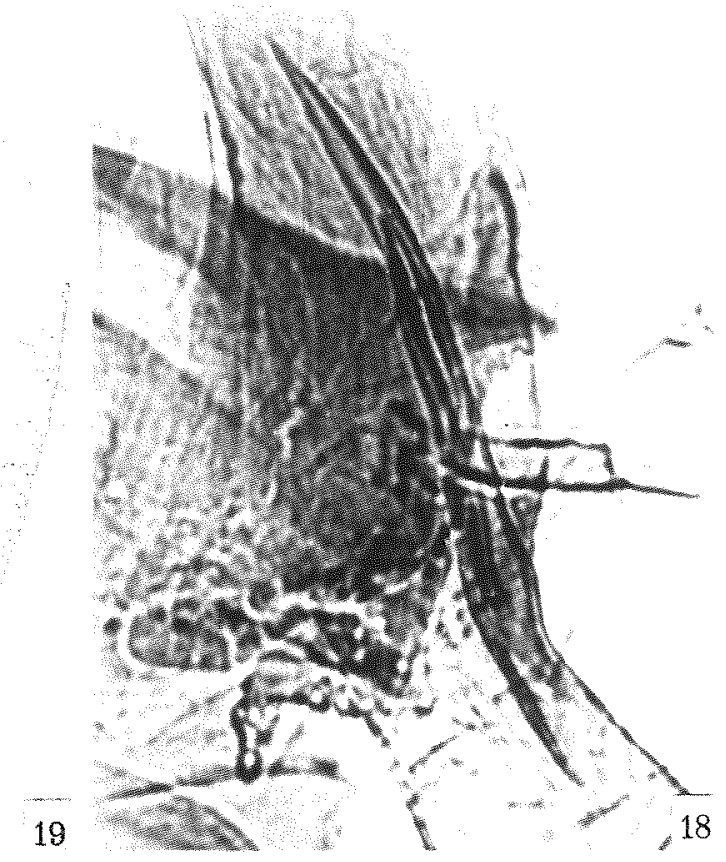

Figs 16-19: Coleopbora okuella BALDIZZONE \& SAVENKOV n. sp., o 16. male genitalia (PG BLDZ 11580 holotypus), 17. detail of genitalia at high magnification, 18. cornuti at high magnification, 19. abdomen. 

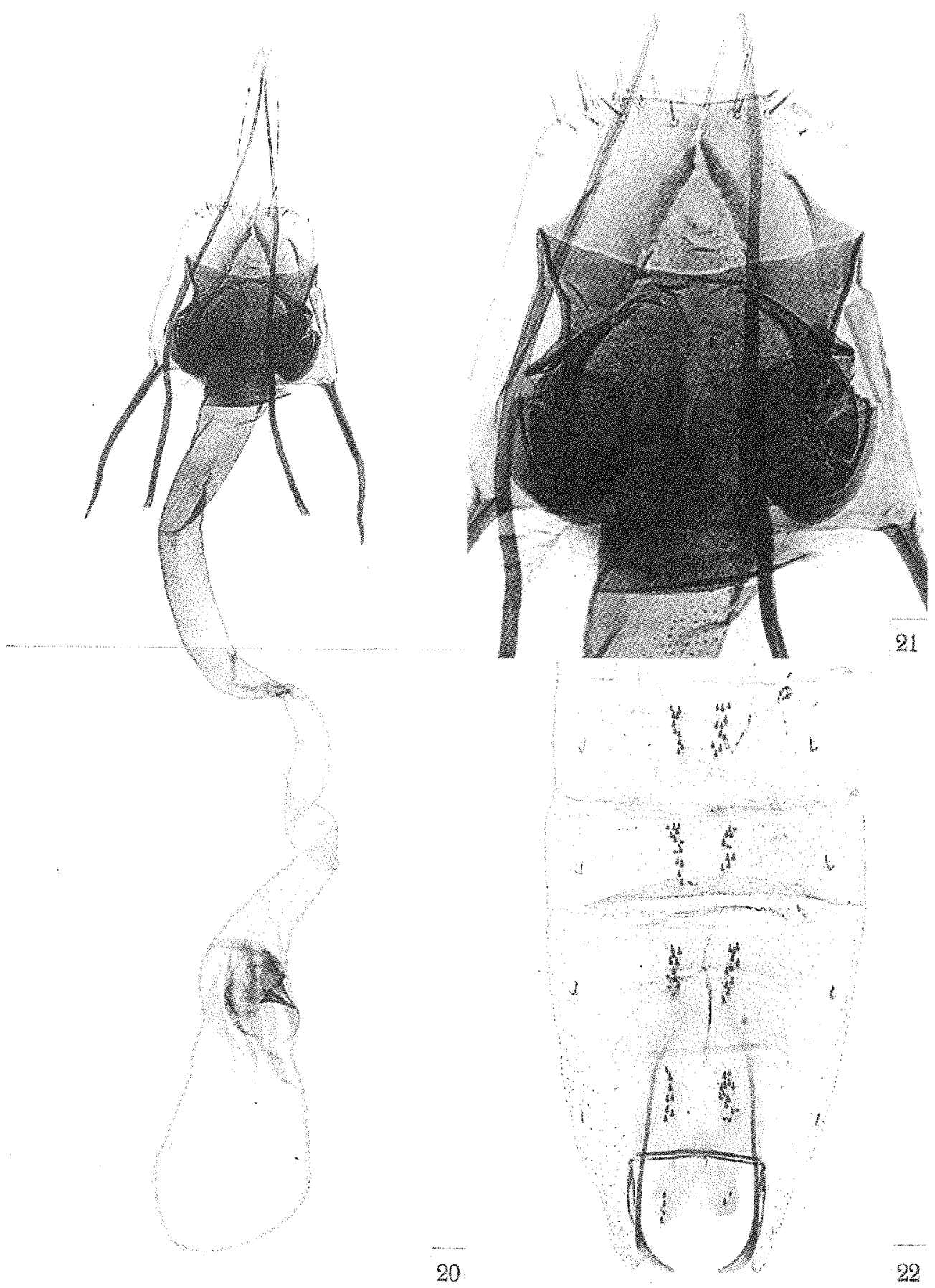

Figs 20-22: Coleophora okuella BALDIZZONE \& SAVENKOv n. sp., o 20. female genitalia (PG BLDZ 11706 - paratype), 21. sterigma at high magnification, 22. abdomen. 

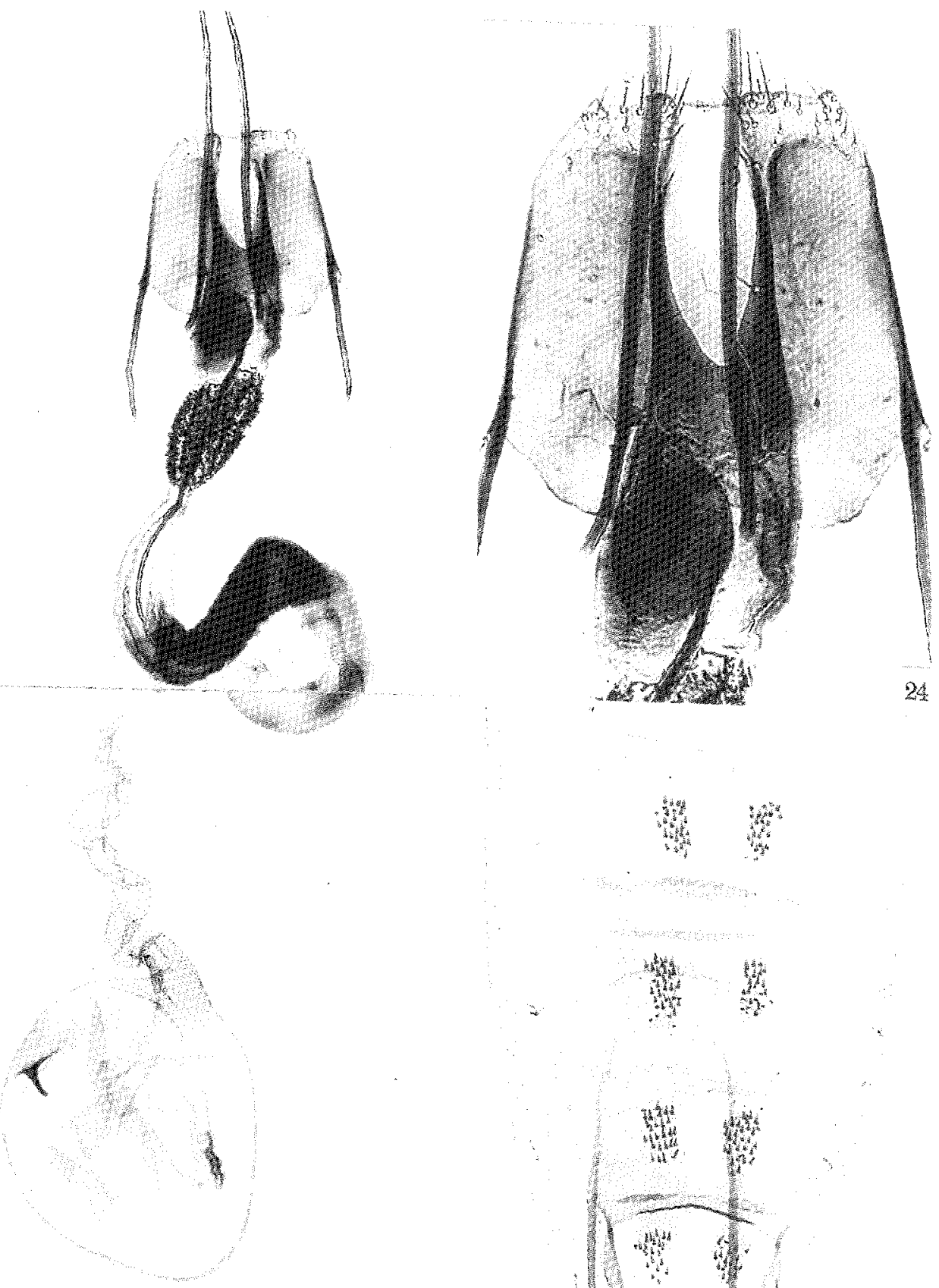

Figs 23-25: Coleophora cristata BALDIZZONE, \& 23. female genitalia (PG BLOZ 11711), "Primorskij Ktai, Shkotovo distr., Anisimovka, 7.08.1004, N. SAVENKor", 24. sterigma at high magnification, 25. abdomen. 

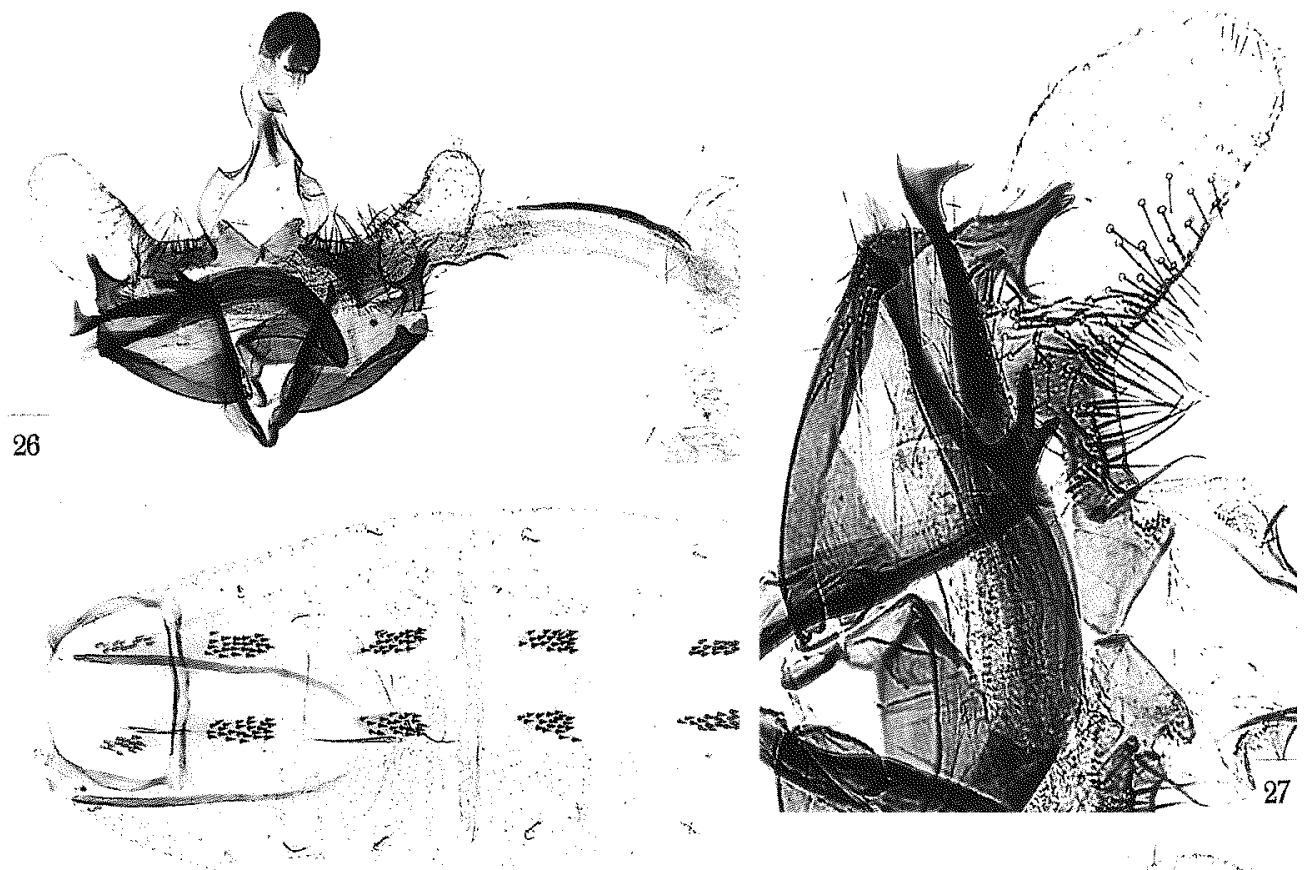

31
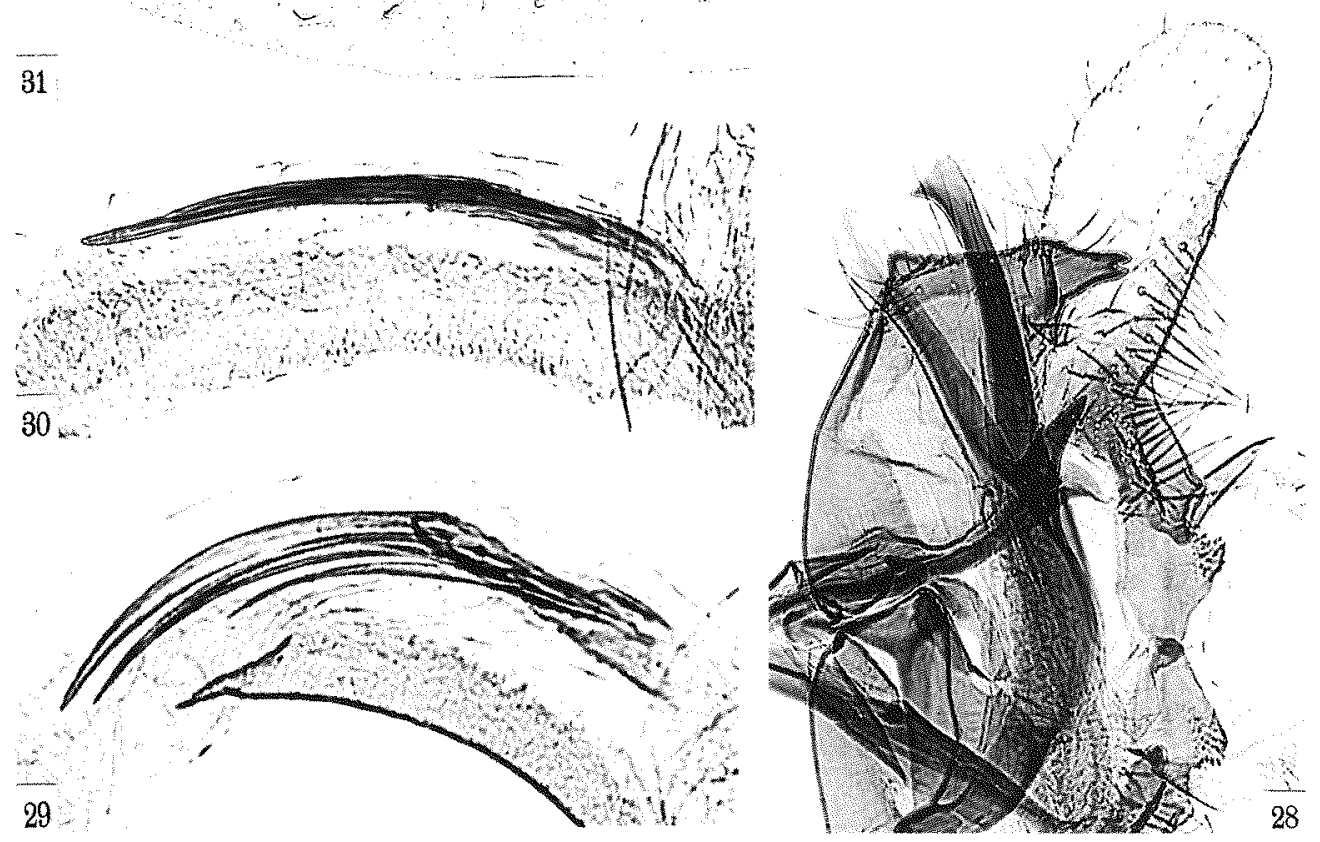

Figs 26-31: Coleophora kamchatica ANIKIN, ơ 26. male genitalia (PG Bl.DZ 11559) "Primorskij Kraj, Hasan distr., Bamburovo, 23.08,1990, A. Napolov", 27. detail of genitalia at high magnification, 28. same detail (PG BLDZ 11710), same locality and collector, 15.08.1990, 29. cornuti at high magnification (PG BLDZ 11710), 30. cornuti at high magnification (PG BLDZ 11559), 31. abdomen. 

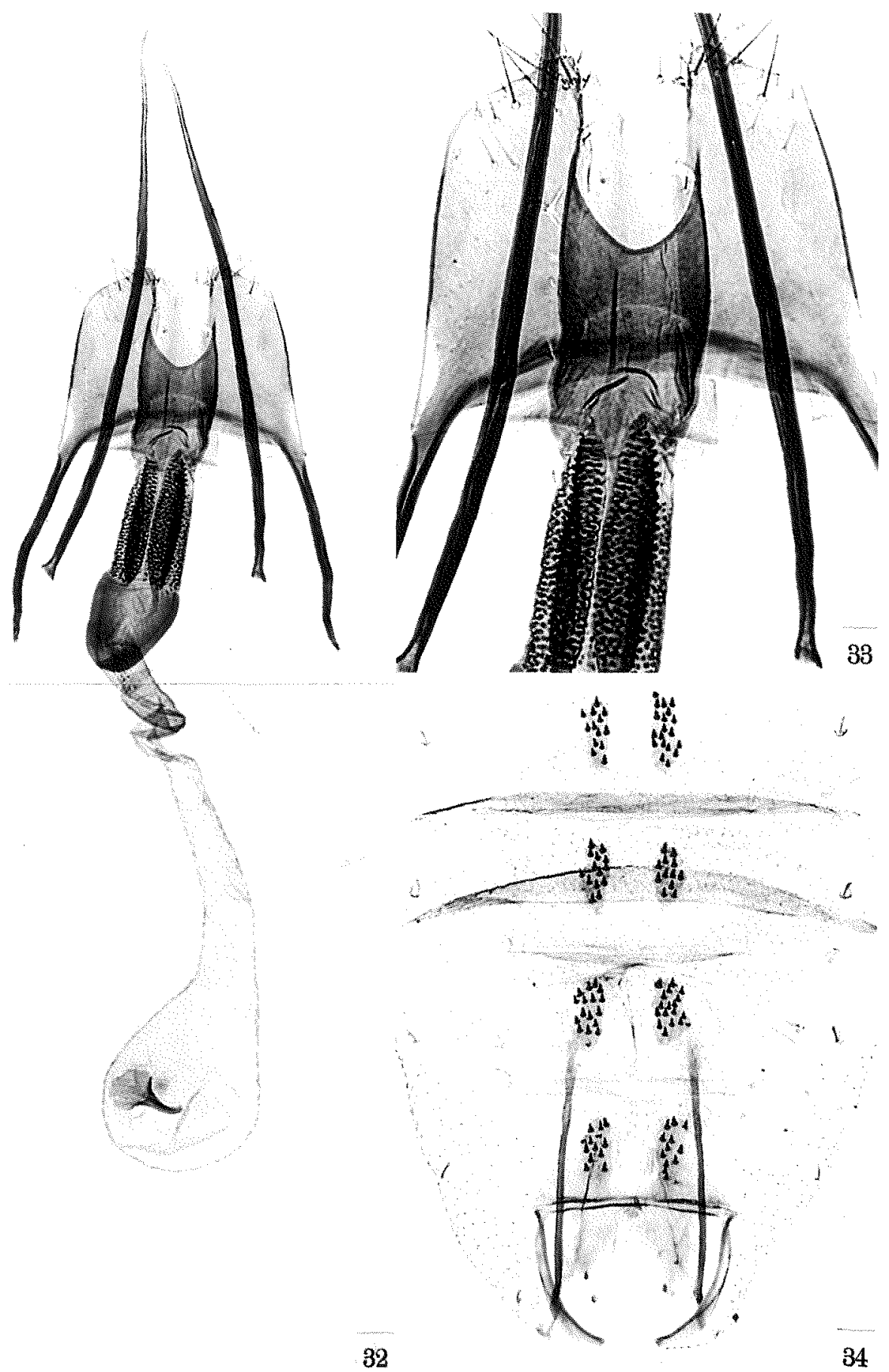

Figs 32-34: Coleophora falkenvitshella VIVES, o 32. female genitalia (PG BLDZ 11689) "Primorskij Kraj, Shkotovo distr., Anisimovka, 3.08.1004, N. SAVENKOV", 33. sterigma at high magnification, 34. abdomen. 


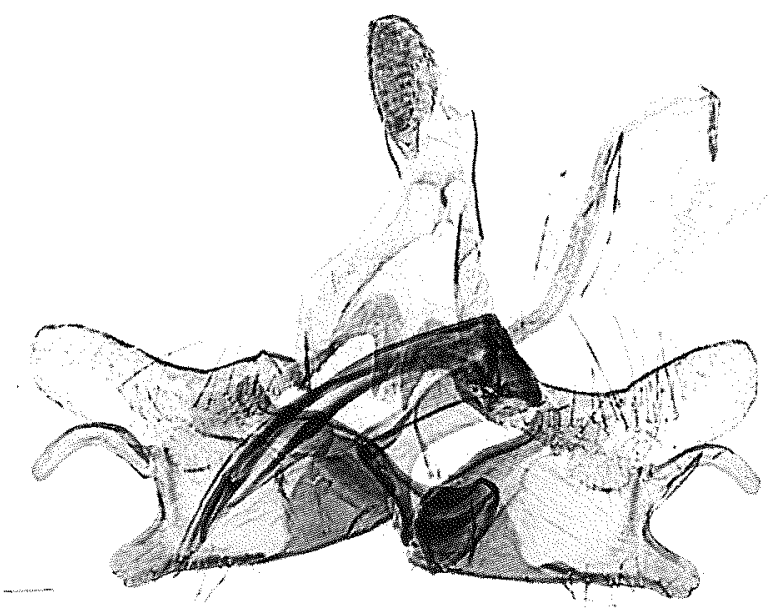

35
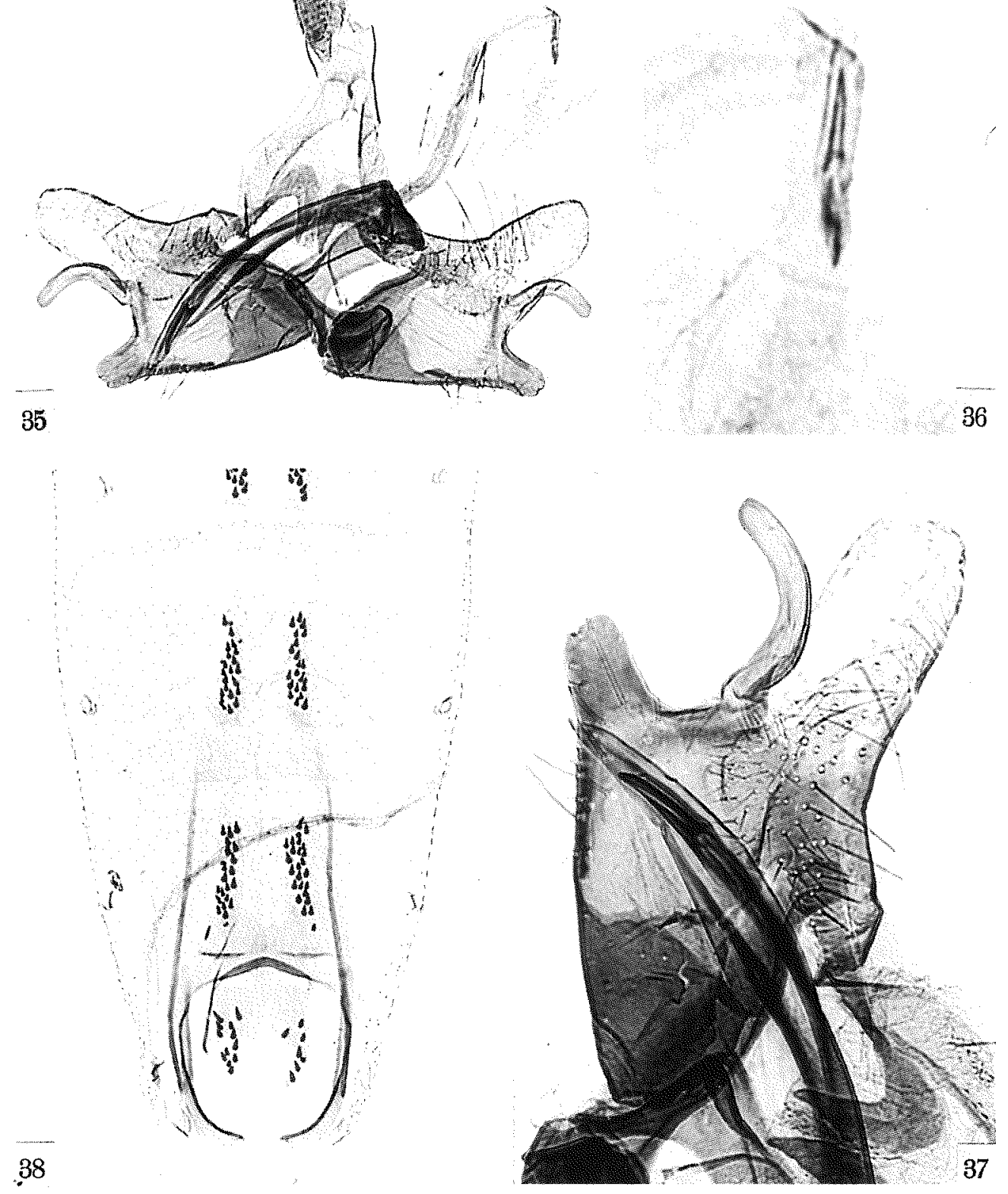

Figs 35-38: Coleophora raphidon BALDIZZONE \& SAVENKOV n. sp., o 35. male genitalia (PG BLDZ 11611 holotype), 36. cornuti at high magnification, 37. detail of genitalia at high magnification, 38. abdomen. 

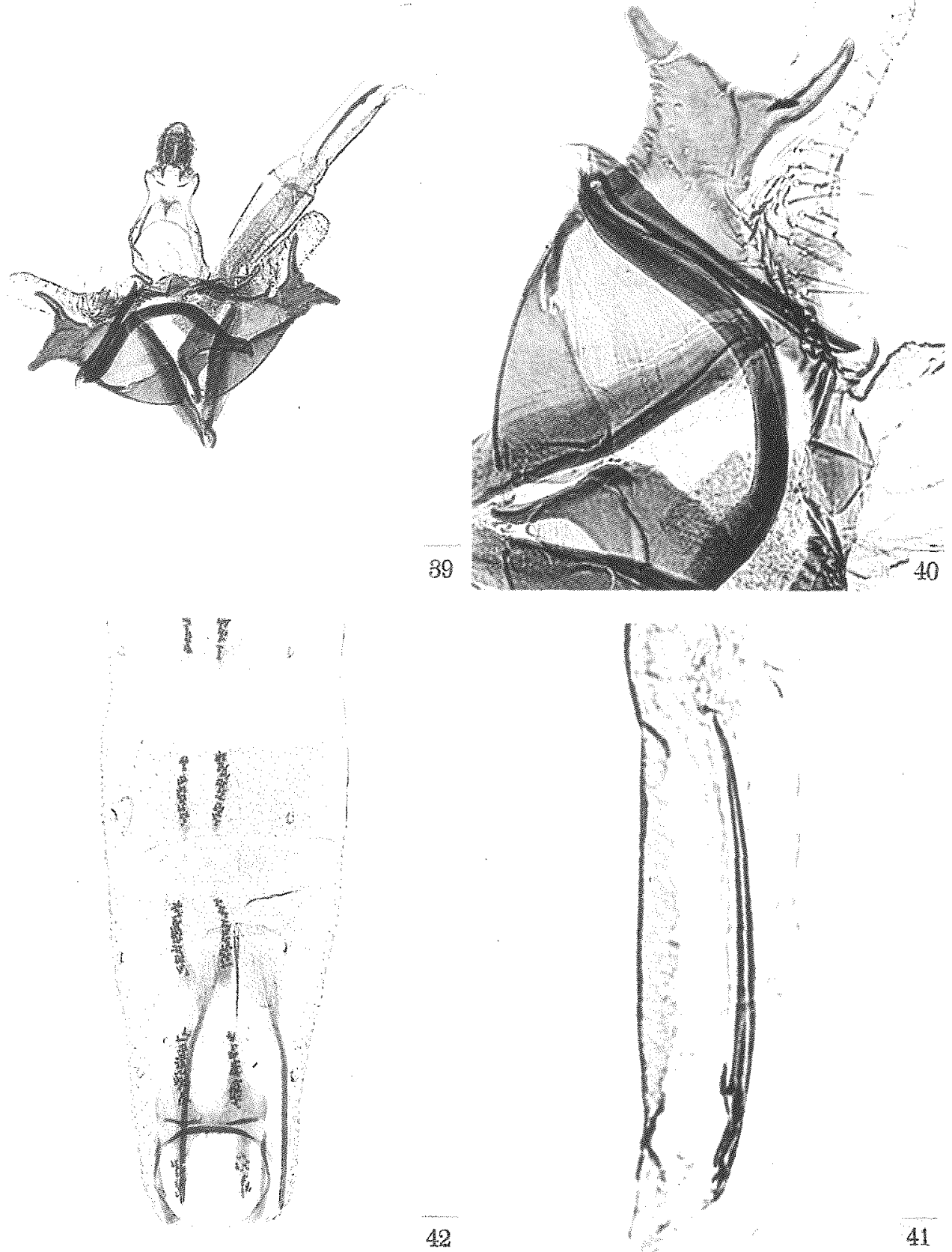

41

Figs 39-42: Coleopbora ininae BALDIZZONE \& SAVENKOV n. sp., o 39. male genitalia (PG BLDZ 11566 holotype), 40. detail of genitalia at high magnification, 41 . cornutus at high magnification, 42. abdomen. 

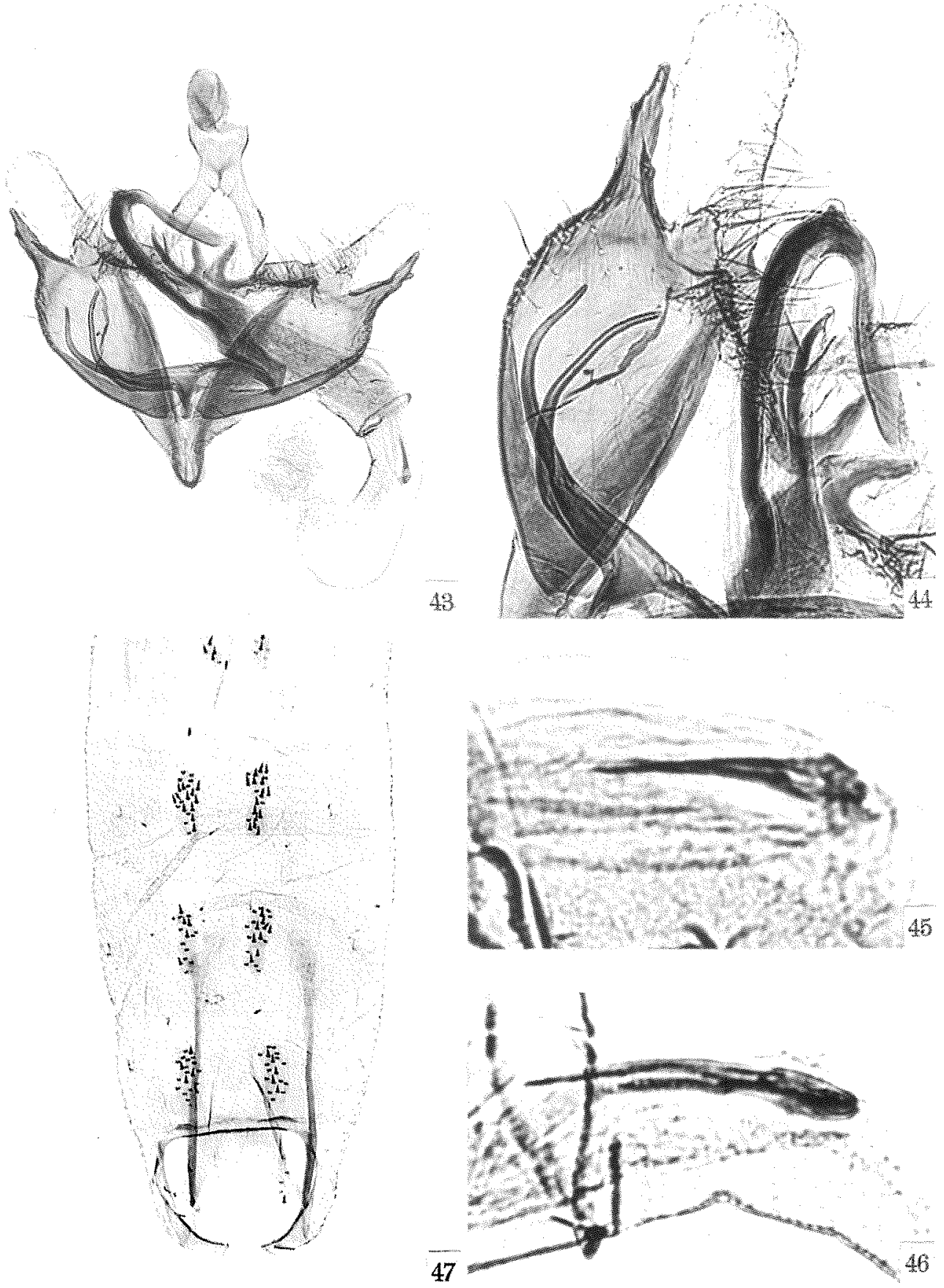

Figs 43-47: Coleophora parki BALDIZZONE \& SAVENKOV n. sp., o 43. male genitalia (PG BLDZ 11701 holotype), 44. detail of genital at high magnification, 45. cornutus at high magification, 46. cornutus at high magnification (PG BLDZ 11605 - paratypus), 47. abdomen. 

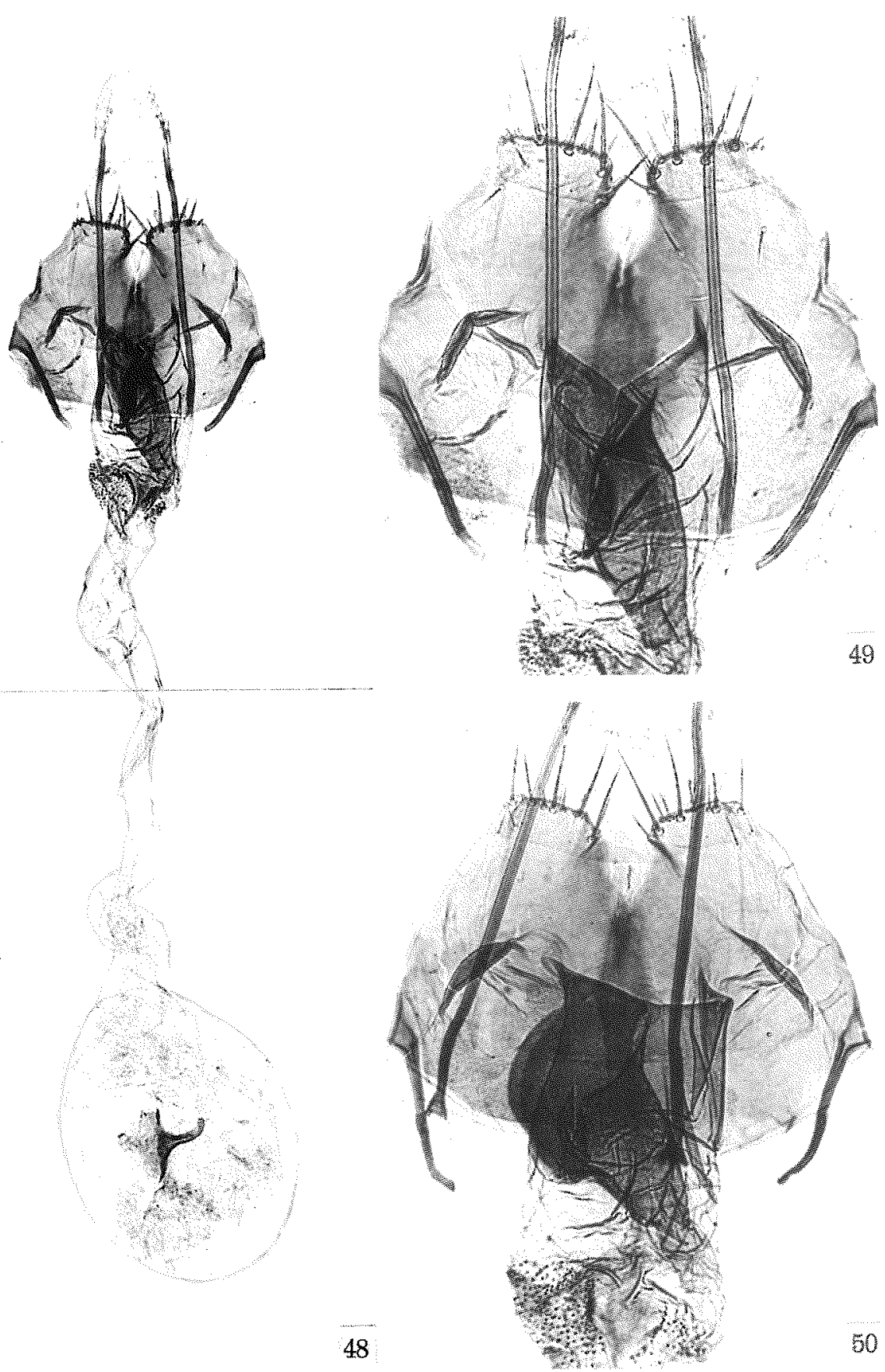

Figs 48-50: Coleophora parki BALDIZZONE \& SAVENKOV n. sp., o 48. female genitalia (PG BLDZ 11612 paratype), 49. stetigma at high magnification, 50. idem (PG BLDZ 11702 - paratypus). 

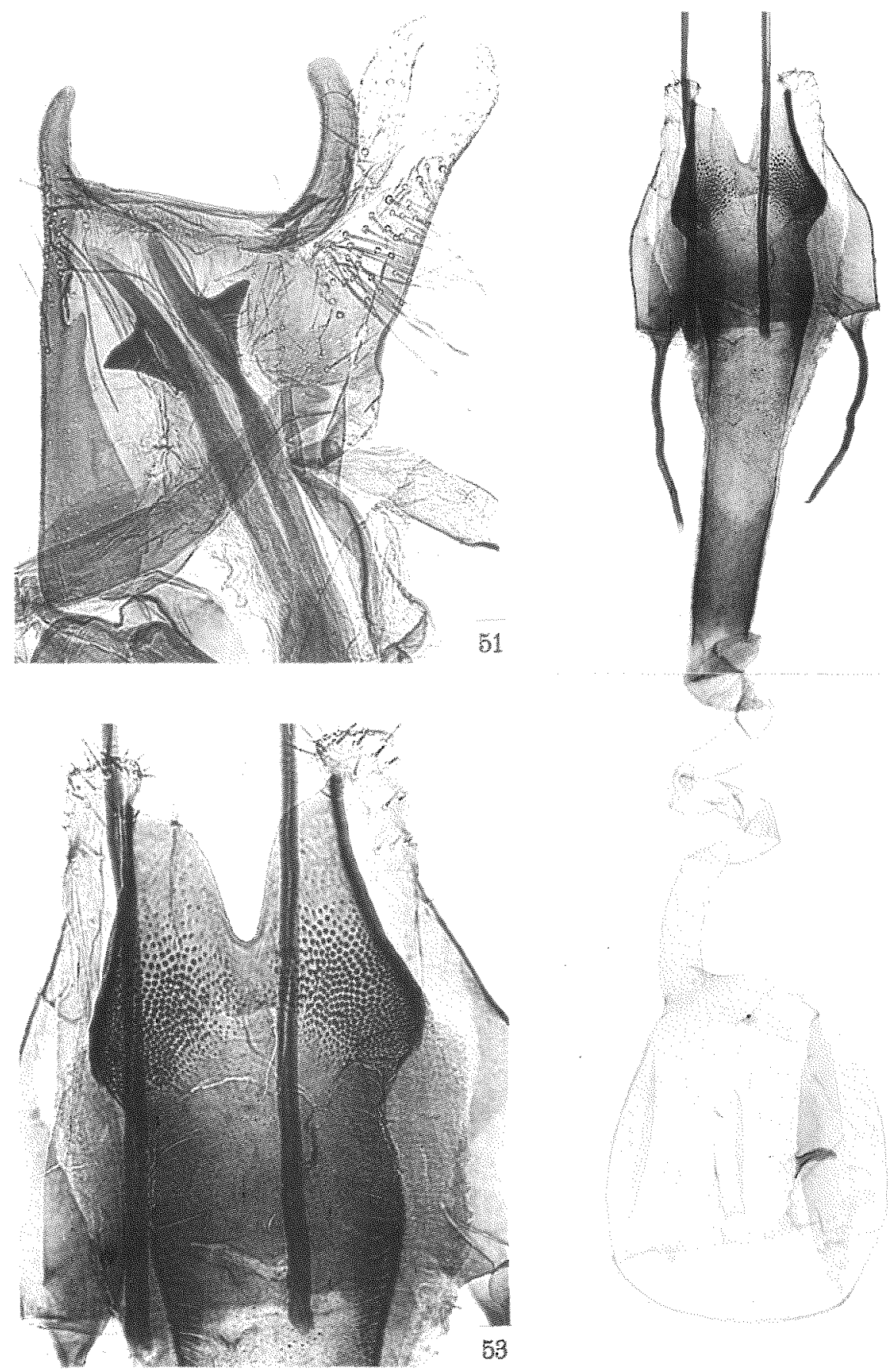

Figs 51-53: Coleophora silenella HERRICH-SCHÄFFER (51: o; 52-53: १) 51. detail of male genitalia at high magnification (PG BLDZ 11697) "Primorskij Kraj, Shkotovo distr., Anisimovka, 5.08.1994, N. SAVENKOV", 52. female genitalia (PG BLDZ 11696), same locality and collector, 29.07.1994, 53. sterigma at high magnification. 


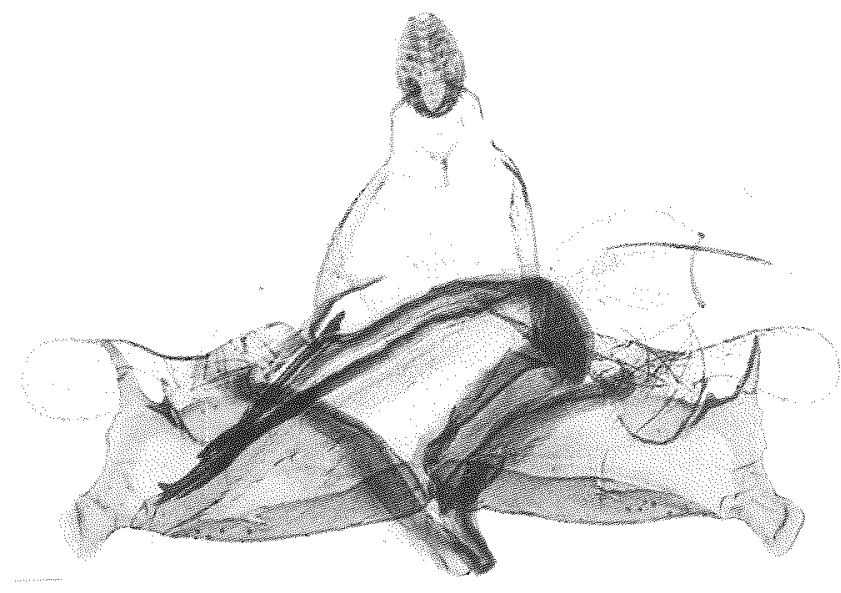

but
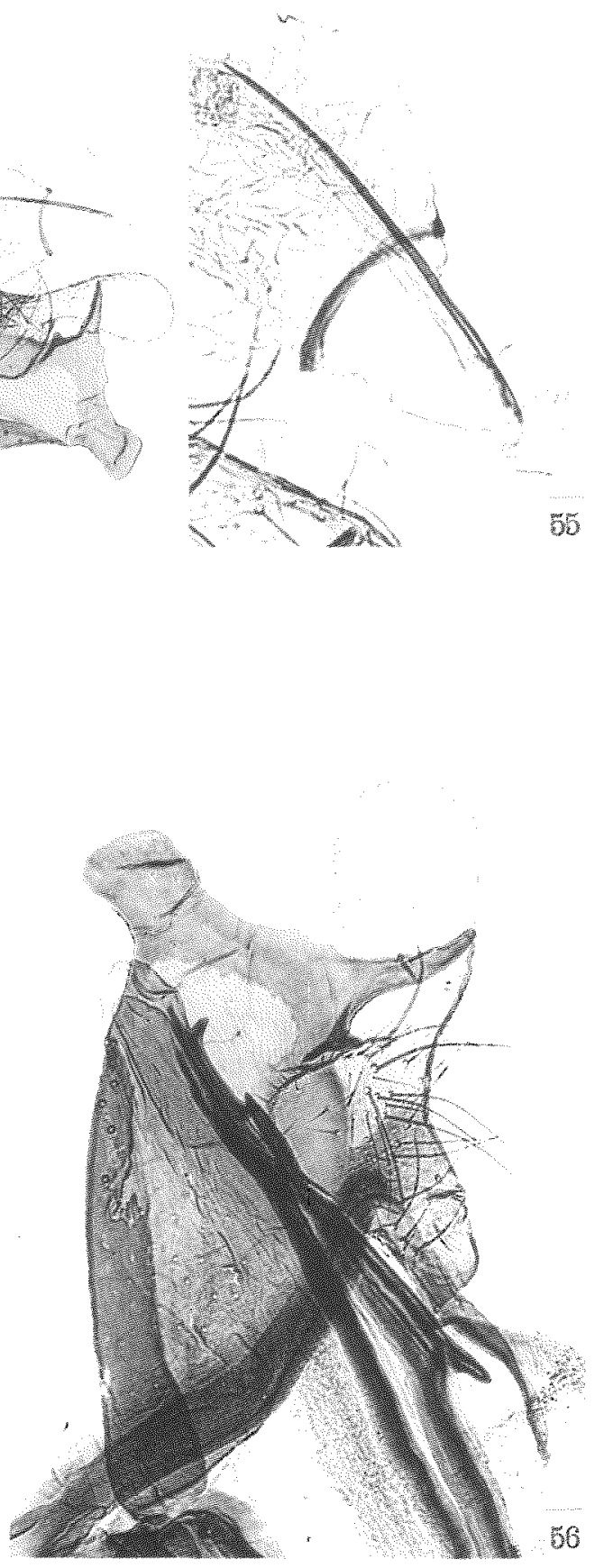

Figs 54-57: Coleopbora napolovi BALDrzZONE \& SAVENKOV n. sp., ơ 54. male genitalia, 55. cornutus at high magnification, 56. detail of male genitalia at high magnification (PG BLDZ 11590 - holotypus), 57. abdomen. 

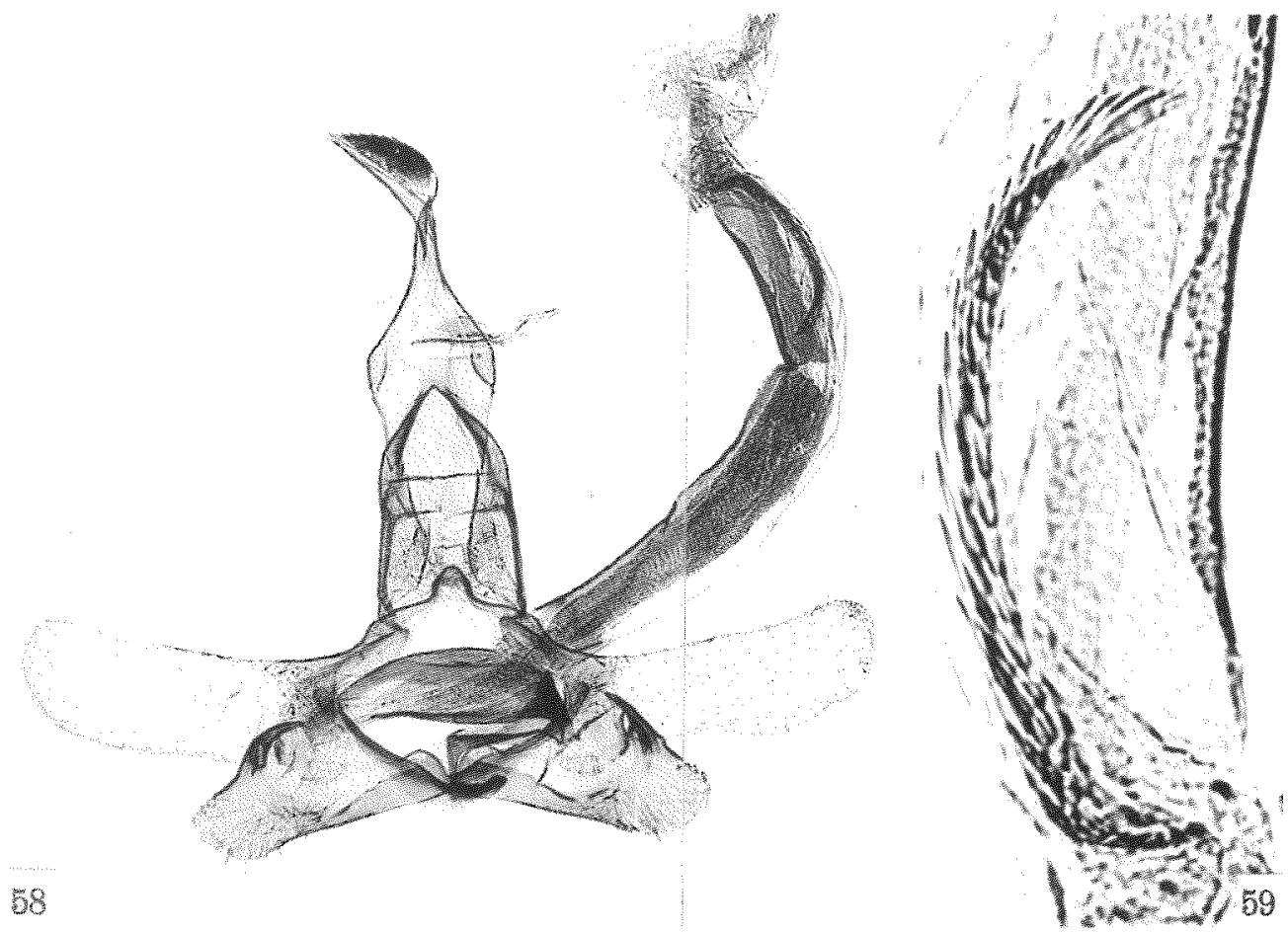

68
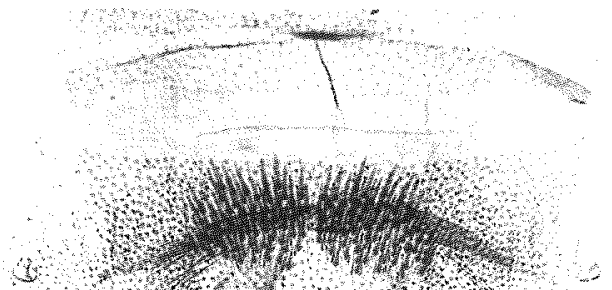

61
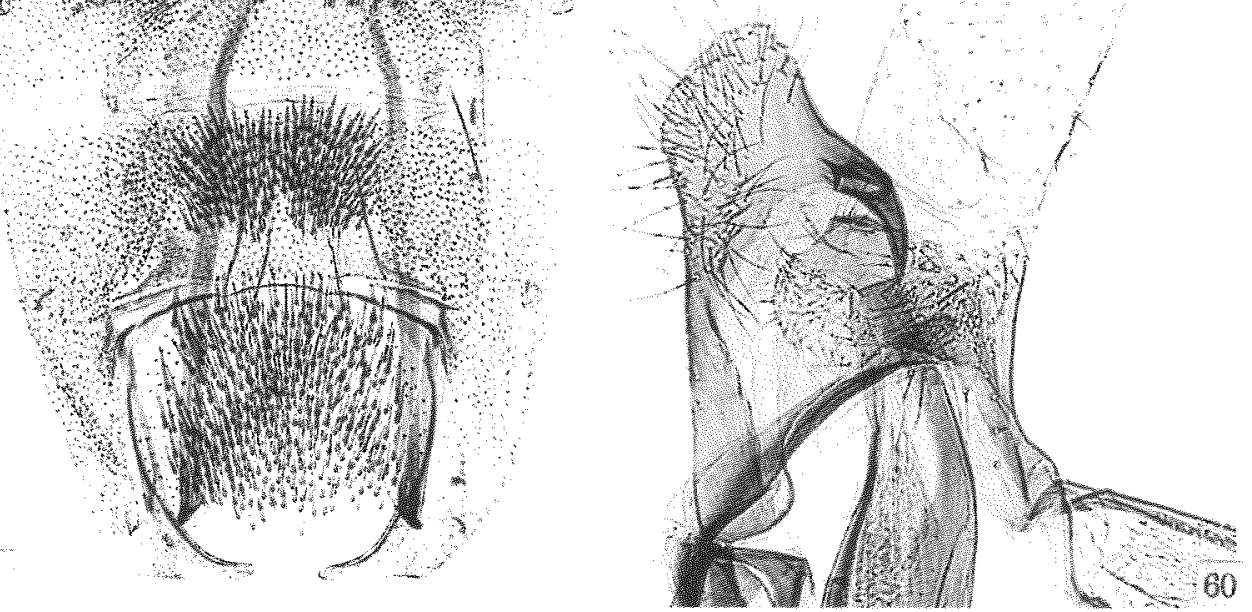

Figs 58-61: Coleophora weimarni ToLL, ơ 58. male genitalia, 59. cornuti at high magnification, 60. detail of male genitalia at high magnification (PG BLDZ 11577) "Primorskij Kraj, Anisimovka, Shkotovo distr., 28.07.1994, N. SAVENKOV”, 61. abdomen. 

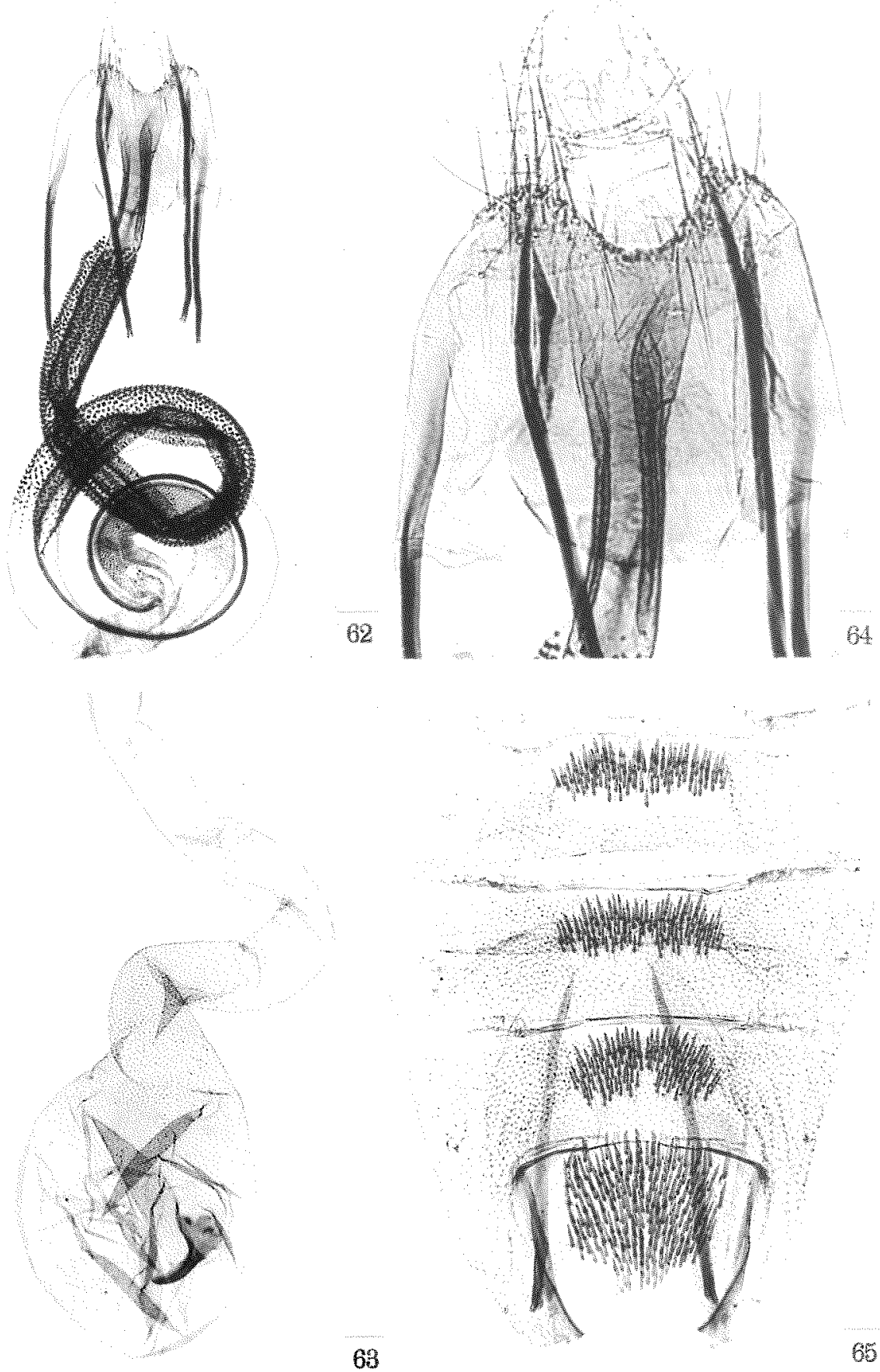

Figs 62-65: Coleophora weimarni'ToLL, \& 62-63. female genitalia (PG BLDZ 11599) "Primorskij Kraj, Shkotovo distr., Anisimovka, 5.08.1994, N. SAVENKOV", 64. sterigma at high magnification, 65. abdomen. 

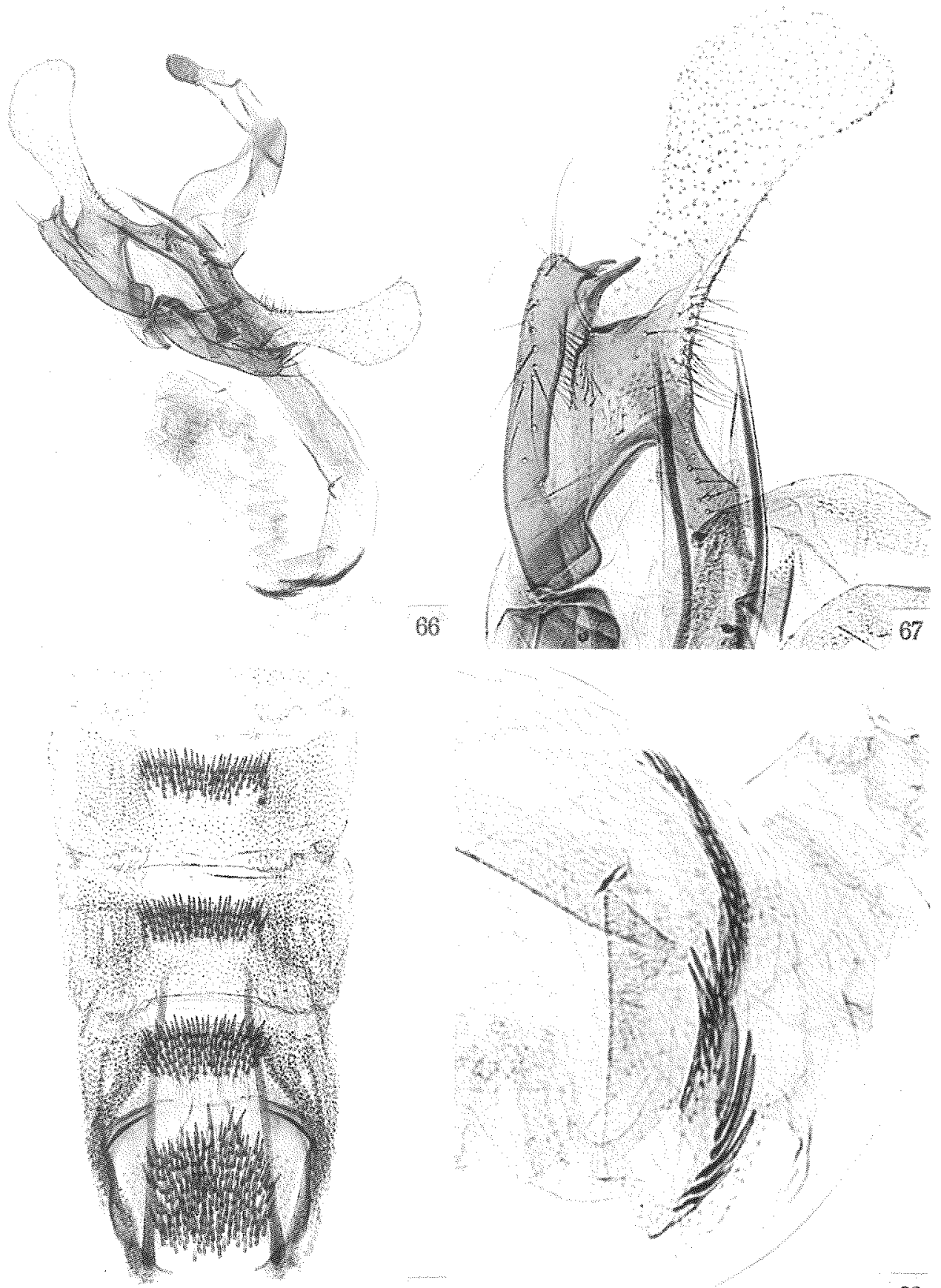

Figs 66-69: Coleophora lativittella ERSCHOFF, o 66. male genitalia (PG BLDZ 11600) "Primorskij Kraj, SSikate-Alim Yasnoye, 28.08.1991, A. NAPOLOV", 67. detail of male genitalia at high magnification, 68. cornuti at high magnification, 69 . abdomen. 

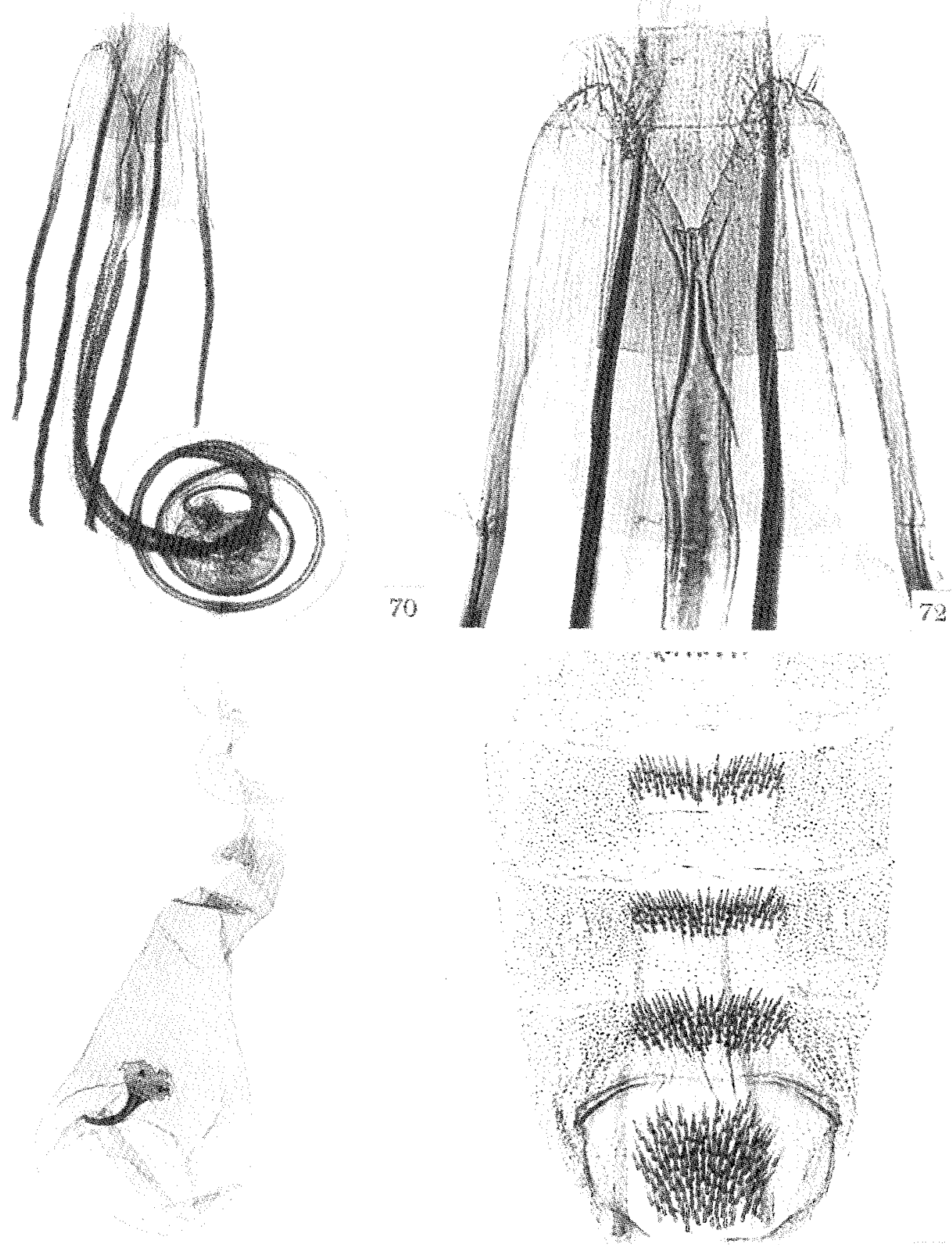

Figs 70-73: Coleopbora lativitiella ERSCHOFF, o 70-71. female genitalia (PG BLDz 11558) "Prinorskij Ktaj, Hasan distr., 23.08.1990, Bamburovo, A. Napolov", 72. sterigma at high magnification, 73. abdomen. 